\title{
RESEARCH AND RECOVERY
}

OF SNAKE RIVER

\section{SOCKEYE SALMON}

Annual Report For April 1994 - April 1995

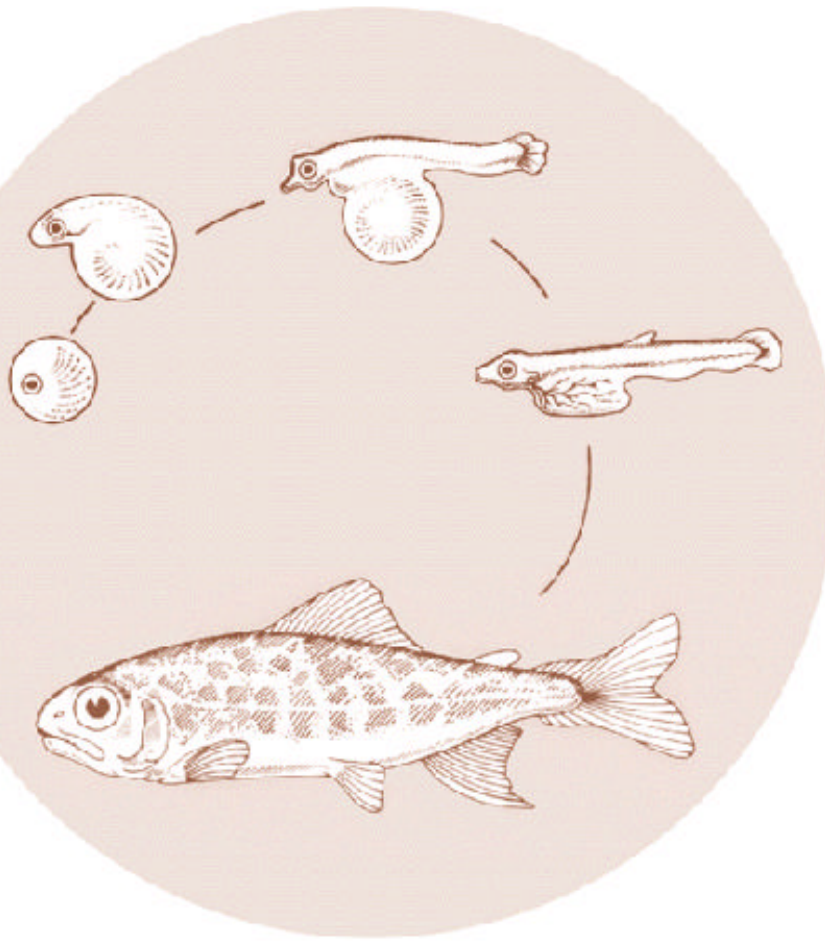

DOE/BP-21065-5 
This report was funded by the Bonneville Power Administration (BPA), U.S. Department of Energy, as part of BPA's program to protect, mitigate, and enhance fish and wildlife affected by the development and operation of hydroelectric facilities on the Columbia River and its tributaries. The views of this report are the author's and do not necessarily represent the views of BPA.

This document should be cited as follows:

Johnson, Keith A., Jay. J. Pravecek - Idaho Department of Fish and Game, 1996, Research and Recovery of Snake River Sockeye Salmon, Annual Report for April 1994 - April 1995, Report to Bonneville Power Administration, Contract No. 1991BP21065, Project No. 199107200, 51 electronic pages (BPA Report DOE/BP-21065-5)

This report and other BPA Fish and Wildlife Publications are available on the Internet at:

\section{http://www.efw.bpa.gov/cgi-bin/efw/FW/publications.cgi}

For other information on electronic documents or other printed media, contact or write to:

Bonneville Power Administration

Environment, Fish and Wildlife Division

P.O. Box 3621

905 N.E. 11th Avenue

Portland, OR 97208-3621

Please include title, author, and DOE/BP number in the request. 


\title{
RESEARCH AND RECOVERY OF SNAKE RIVER SOCKEYE SALMON
}

\author{
ANNUAL REPORT FOR APRIL 1994 - APRIL 1995
}

\author{
Prepared by: \\ Keith A. Johnson, Principal Fisheries Research Biologist \\ Jay J. Pravecek, Fish Culturist \\ Idaho Department of Fish and Game \\ Eagle, ID 83616
}

Prepared for:

U. S. Department of Energy

Bonneville Power Administration

Environment, Fish and Wildlife

P.O. Box 3621

Portland, OR 97208-362 1

IDFG 96-16

Project Number 9 1-72

Contract Number DE-BI79-9 1 BP2 1065

SEPTEMBER 1996 


\section{TABLE OF CONTENTS}

Page

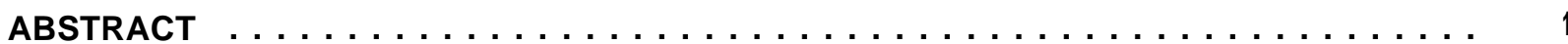

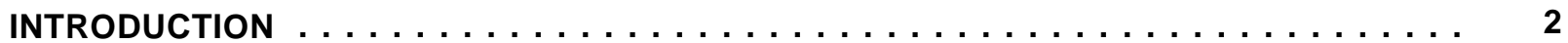

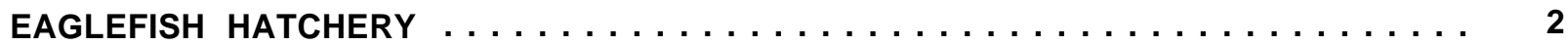

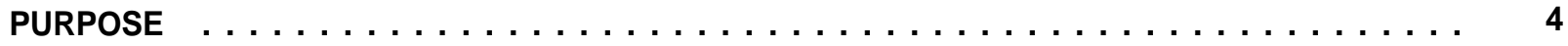

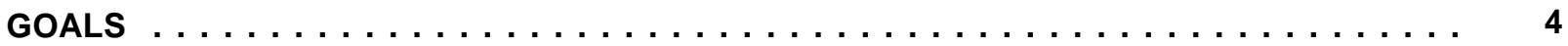

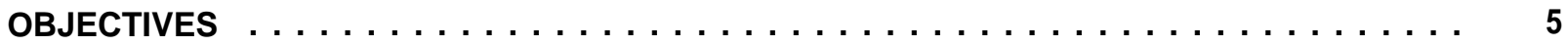

Current Practices to Achieve These Objectives . . . . . . . . . . . . . . . 5

Fish Hatchery Production ...................... 5

Minimize Interactions with Other Fish Populations Through Proper

Rearing and Release Strategies .................... 5

Maintain Stock Integrity and Genetic Diversity . . . . . . . . . . . . . 6

Management of Bacterial Kidney Disease in Broodstocks . . . . . . . . . 6

PERFORMANCE OF CULTURED GROUPS . . . . . . . . . . . . . . . . . . . . . . 6

Outmigrants $1991 \ldots \ldots \ldots \ldots \ldots$

B roodYe a $\ldots \ldots \ldots \ldots \ldots \ldots$

Outmigrants $1992 \ldots \ldots \ldots \ldots \ldots$

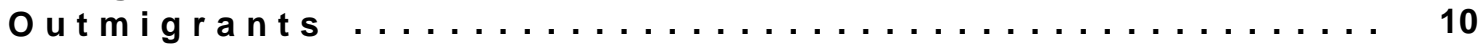

Residual Brood Year $1992 \ldots \ldots \ldots$

Anadromous Brood Year 1993 ... . . . . . . . . . . . . . . . . . 10

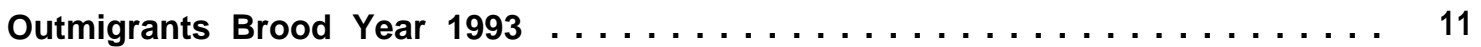

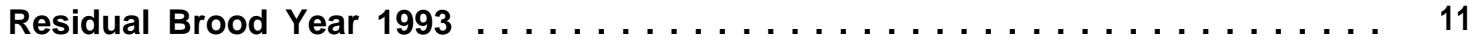

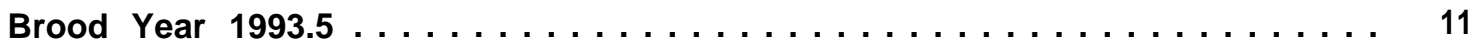

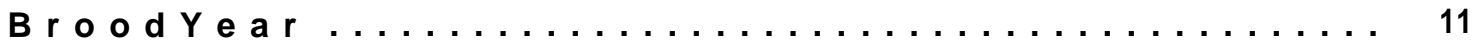

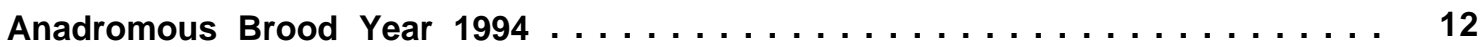

ADULT TRAPPING AT REDFISH LAKE CREEK . . . . . . . . . . . . . . . . . . . . . . . . 12

SPAWNING ACTIVITIES FOR $1994 \ldots \ldots$. . . . . . . . . . . . . . . . . . . . . .

Spawning Matrix and Genetic Identity of Broodstocks . . . . . . . . . . . . . 13

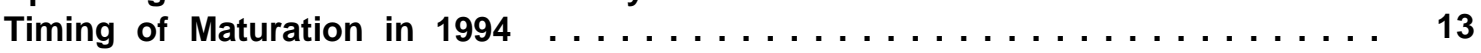

General Spawning Protocol . . . . . . . . . . . . . . . . . . . . . 13

"Off Season" Matings . April to August $1994 \ldots \ldots \ldots \ldots$. . . . . . . . . . . 15

Spermatozoa Quality Estimation . . . . . . . . . . . . . . . . . . . . . . . . . . . . . . . . . . . . . . . . . . . . . . .

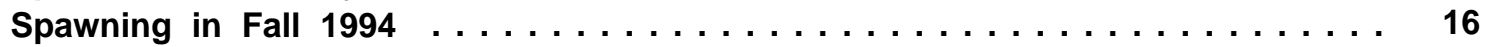

Timing of Maturity . . . . . . . . . . . . . . . . . . . . . 17

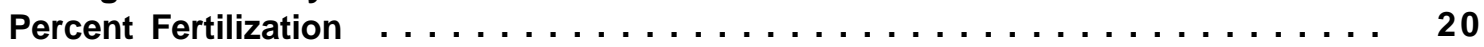

Potential for Inbreeding ........................... 20

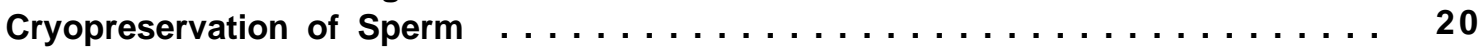




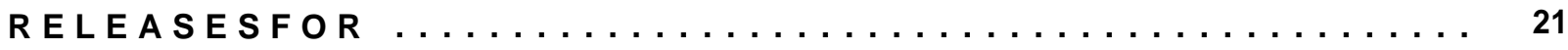

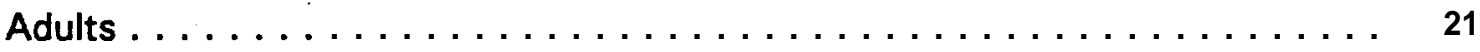

Release Strategies for Juvenile Sockeye Salmon $\ldots \ldots \ldots \ldots \ldots \ldots \ldots \ldots \ldots 21$

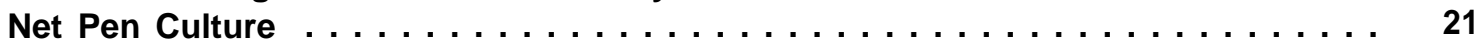

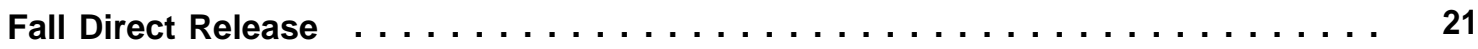

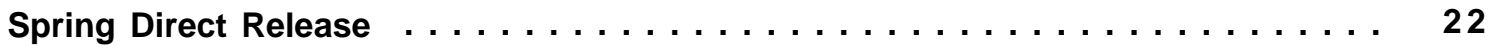

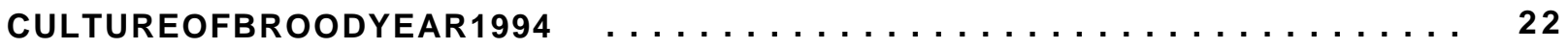

Incubation $\ldots \ldots \ldots \ldots \ldots \ldots \ldots \ldots \ldots \ldots \ldots \ldots \ldots \ldots, 22$

Egg Lots Received from NMFS $\ldots \ldots \ldots \ldots \ldots \ldots \ldots \ldots \ldots \ldots \ldots, 22$

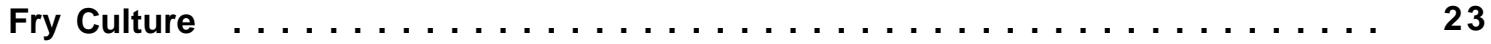

CAPTIVE BROODSTOCK RESEARCH $\ldots \ldots \ldots \ldots \ldots \ldots \ldots \ldots \ldots \ldots \ldots, 23$

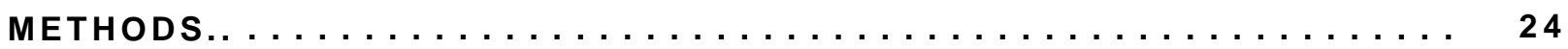

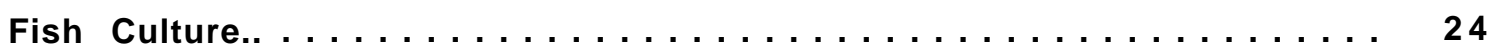

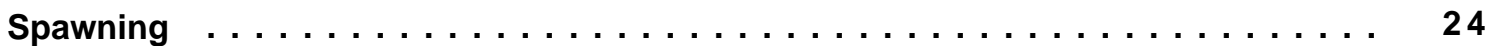

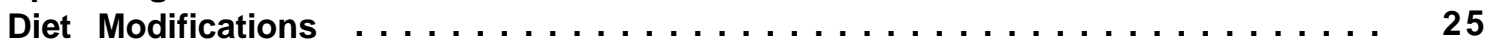

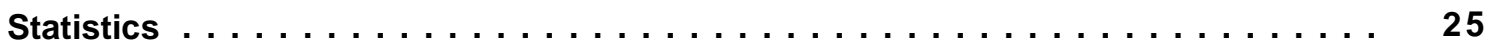

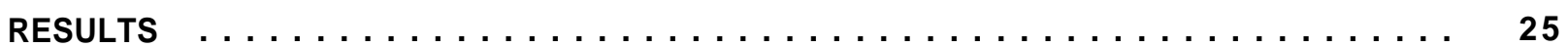

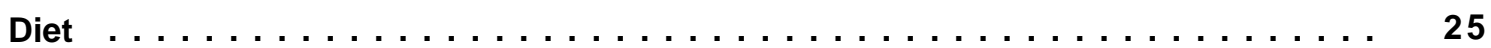

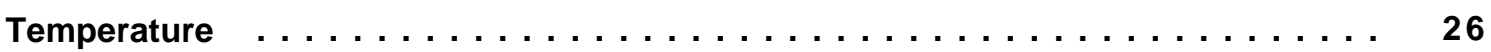

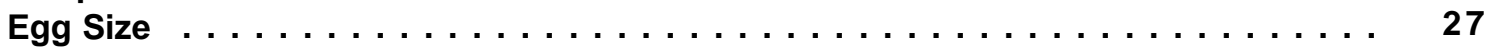

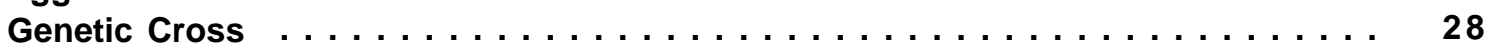

FACILITY MODIFICATIONS $\ldots \ldots \ldots \ldots \ldots \ldots \ldots \ldots \ldots \ldots \ldots \ldots \ldots \ldots \ldots \ldots \ldots, 29$

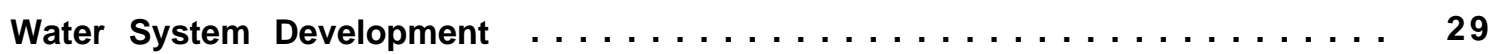

Rearing Capacity Increases at Eagle Fish Hatchery $\ldots \ldots \ldots \ldots \ldots \ldots \ldots, 30$

Additional Capital Purchases $\ldots \ldots \ldots \ldots \ldots \ldots \ldots \ldots \ldots \ldots \ldots \ldots \ldots \ldots \ldots \ldots$

Major Maintenance Projects $\ldots \ldots \ldots \ldots \ldots \ldots \ldots \ldots \ldots \ldots \ldots, 31$

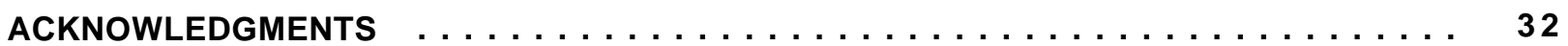

LiteRATURECITED $\ldots \ldots \ldots \ldots \ldots \ldots \ldots \ldots \ldots \ldots \ldots \ldots \ldots \ldots \ldots \ldots \ldots$

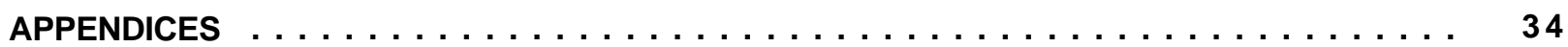




\section{LIST OF TABLES}

Table 1. Recent run sizes of sockeye salmon passing Lower Granite Dam . . . . . . 4

Table 2. List of existing facilities for incubating and rearing fish at Eagle Fish

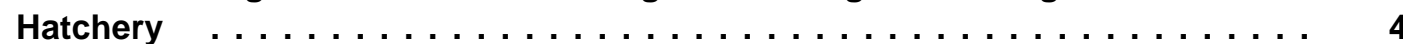

Table 3. Abbreviations used in the text $\ldots \ldots \ldots \ldots \ldots \ldots \ldots$

Table 4. Summary of mortality for four groups of Redfish Lake sockeye salmon captive broodstocks from April 1991 to April $1995 \ldots \ldots \ldots \ldots \ldots$. . . . .

Table 5. Results of spawnings made with Redfish Lake sockeye salmon captive broodstocks at Eagle Fish Hatchery from April through August 1994 . . . . 16

Table 6. The effect of diet on percent maturation of captive sockeye salmon broodstock ............................

Table 7. The effect of diet on initial fertilization $(48 \mathrm{~h})$ of captive sockeye salmon

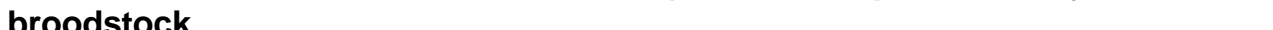

Table 8. The effect of diet on female performance of captively reared sockeye

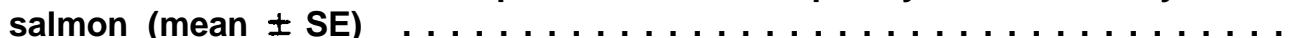

Table 9. The effect of diet on egg survival percentages of captive Redfish Lake sockeye salmon at two incubation temperatures (mean $\pm \mathrm{SE}$ ) ....... 27

Table 10. Egg survival percentages of 98 captive sockeye salmon incubated at two

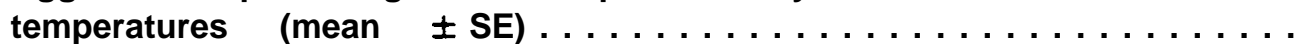

Table 11. The effect of egg size (number of eggs per gram) on egg survival percentages of Redfish Lake sockeye salmon at two incubation temperatures (mean \pm SE) . . . . . . . . . . . . . . . .

Table 12. The effect of mating cross on egg survival percentages of captive Redfish Lake sockeye salmon at two incubation temperatures (mean $\pm \mathrm{SE}$ ) .....

Table 13. Egg survival and female performance for the 1994 fall spawning season . . .

\section{LIST OF FIGURES}

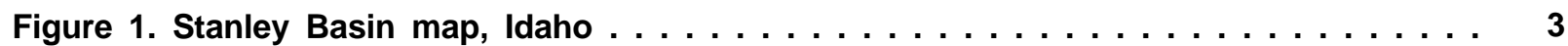

Figure 2. Maturation time line for 1993-1994 female spawners . . . . . . . . . . . 14

Figure 3. BY91 female spawner performance for $1994 \ldots \ldots \ldots \ldots \ldots$ 


\section{LIST OF FIGURES (Cont.1}

Page

Figure 4. Percent eye by spawn day for the 1994 spawning season . . . . . . . . . 19

\section{LIST OF APPENDICES}

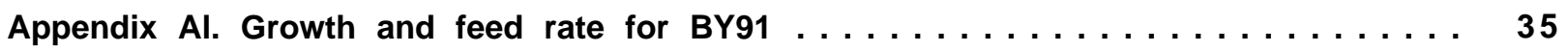

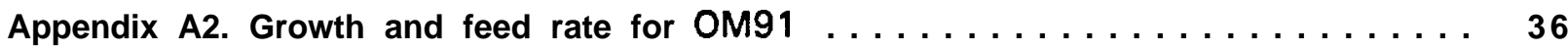

Appendix A3. Growth, feed rate, and size at maturity for OM92 $\ldots \ldots \ldots \ldots \ldots$

Appendix A4. Growth and feed rate for $0 M 93 \ldots \ldots \ldots \ldots \ldots \ldots$

Appendix A5. Growth, feed rate, and size at maturity for RESBY92 . . . . . . 39

Appendix A6. Growth and feed rate for ANBY93 $\ldots \ldots \ldots \ldots \ldots \ldots \ldots$

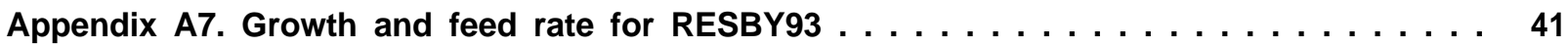

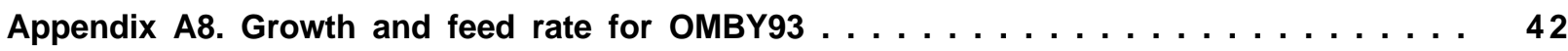

Appendix B. Mating crosses made with anadromous, captive broodstock, and residual adults of Redfish Lake stock during the period of April 1994 through November 1994. Number of females listed first followed by the number of males used by genetic origin $\ldots \ldots \ldots \ldots \ldots$

Appendix C. Adult releases to Redfish Lake for $1994 \ldots \ldots \ldots \ldots \ldots \ldots \ldots$ 
In 1991, the National Marine Fisheries Service (NMFS) listed Snake River sockeye salmon Oncorhynchus nerka as endangered under the Endangered Species Act of 1973. Initial steps to recover the species include the establishment of captive broodstocks at the Idaho Department of Fish and Game (IDFG) Eagle Fish Hatchery in Eagle, Idaho. Research and recovery activities for sockeye salmon conducted by IDFG during the period of April 1994 to April 1995 are covered by this report.

One female anadromous adult returned to the Redfish Lake Creek trap this year. She was spawned at Eagle Fish Hatchery on October 21, 1994. Her fecundity was 2,896. The mean fertilization rate and percent swim-up were $96 \%$ and $95 \%$, respectively. Four hundred eighty eyed eggs were shipped to the NMFS Big Beef Creek Fish Hatchery in Washington state, leaving 2,028 fish on site at Eagle. Additionally, captive broodstock and wild residual sockeye salmon (captured at Redfish Lake) were spawned. Spawning data from 234 females spawned during this period are included in this report. Other spawning data (i.e., genetic cross and incubation temperature) are included in the Captive Broodstock Research section of this report.

A portion of the captive broodstock matured earlier than normal (spring and summer 1994) and exhibited poor fertilization rates. Fish were spawned and samples were taken to investigate reasons for poor fertilization rates.

Sixty captive broodstock adults were selected for return to Redfish Lake for volitional spawning. Releases were made in August and September 1994. Additionally, 19 male residual brood year 1992 adults were released into Redfish Lake on October 5, 1994. A portion of these fish were implanted with sonic tags and tracking of this group began soon after the release to identify spawning-related activities.

A research project was conducted on captive broodstock diets. The project investigated the effect of diet modification on spawn timing, gamete quality, and fertilization rates. The diet contained Antarctic krill as a protein source, as well as an elevated level of selenium. The diet affected female size, egg size, and initial fertilization rates $(P<0.05)$. However, gamete performance (i.e., percent eye-up and percent swim-up) was not affected.

The performance of all captive groups held at Eagle is included in this report.

Numerous modifications were made to Eagle Fish Hatchery during the report period.

Authors:

Keith A. Johnson

Principal Fisheries Research Biologist

Jay J. Pravecek

Fish Culturist 


\section{INTRODUCTION}

Historically, large numbers of adult sockeye salmon Oncorhynchus nerka were reported making the nearly $1,500 \mathrm{~km}$ journey from the ocean to the Stanley Basin lakes of central Idaho. Redfish Lake (Figure 1 ) is now the only lake in the basin which still supports a run of sockeye salmon (Bjornn et al. 1968). In 1991, as a result of only six fish returning to Redfish Lake during the previous three years, the National Marine Fisheries Service (NMFS) declared the Snake River sockeye salmon "endangered" under the Endangered Species Act (ESA) of 1973. The history of the Stanley Basin sockeye salmon runs from 1982-I 993 is found in Table 1.

A technical committee has been established to coordinate efforts to recover this distinct population. The Stanley Basin Sockeye Technical Oversight Committee (SBSTOC) includes representatives of the Idaho Department of Fish and Game (IDFG), NMFS, Bonneville Power Administration (BPA), the Shoshone-Bannock Tribes (SBT), the University of Idaho, -and other state and federal agencies, as well as private groups involved in sockeye salmon restoration in Idaho.

In addition, NMFS is developing a plan to recover Snake River salmon (Snake River Salmon Recovery Plan 1993). This plan includes goals which should result in de-listing the salmon. Currently, one draft goal is for at least 1,000 naturally-produced adults to return to Redfish Lake and at least $\mathbf{5 0 0}$ naturally-produced adults to return to each of two other lakes in the Stanley Basin.

Initial steps by IDFG to recover the species include the establishment of captive broodstocks at Eagle Fish Hatchery in Eagle, Idaho. Seven distinct broodstocks have been established consisting of progeny from Redfish Lake outmigrating smolts, anadromous adults, and residual sockeye salmon. The current report summarizes activities from April 1994 through April 1995 by IDFG at Eagle Fish Hatchery.

\section{EAGLE FISH HATCHERY}

The Eagle Fish Hatchery was recommissioned in 1991 for rearing ESA-listed Snake River sockeye salmon captive broodstocks and their resulting progeny. The site is shared with the IDFG Eagle Fish Health Laboratory. Seven broodstocks from smolts, anadromous adults, and residual stocks have been developed for recovery.

Seven artesian wells are available for fish culture. The water supply was renovated in 1994 to add pumping capability and an intertie between two rearing areas. Effective volume available is approximately $0.2 \mathrm{~m}^{3} \mathrm{~s}^{-1}$. All culture is with first-use water in semi-square or round fiberglass tanks. Table 2 lists the inventory of tanks available for culture use.

Rearing capacity for broodstock is limited by the capacity of a water chiller ( $~ 600$ adults per year). Production capacity has yet to be determined, but is estimated to be 150,000 presmolts per year, consisting of two size/time classes. 


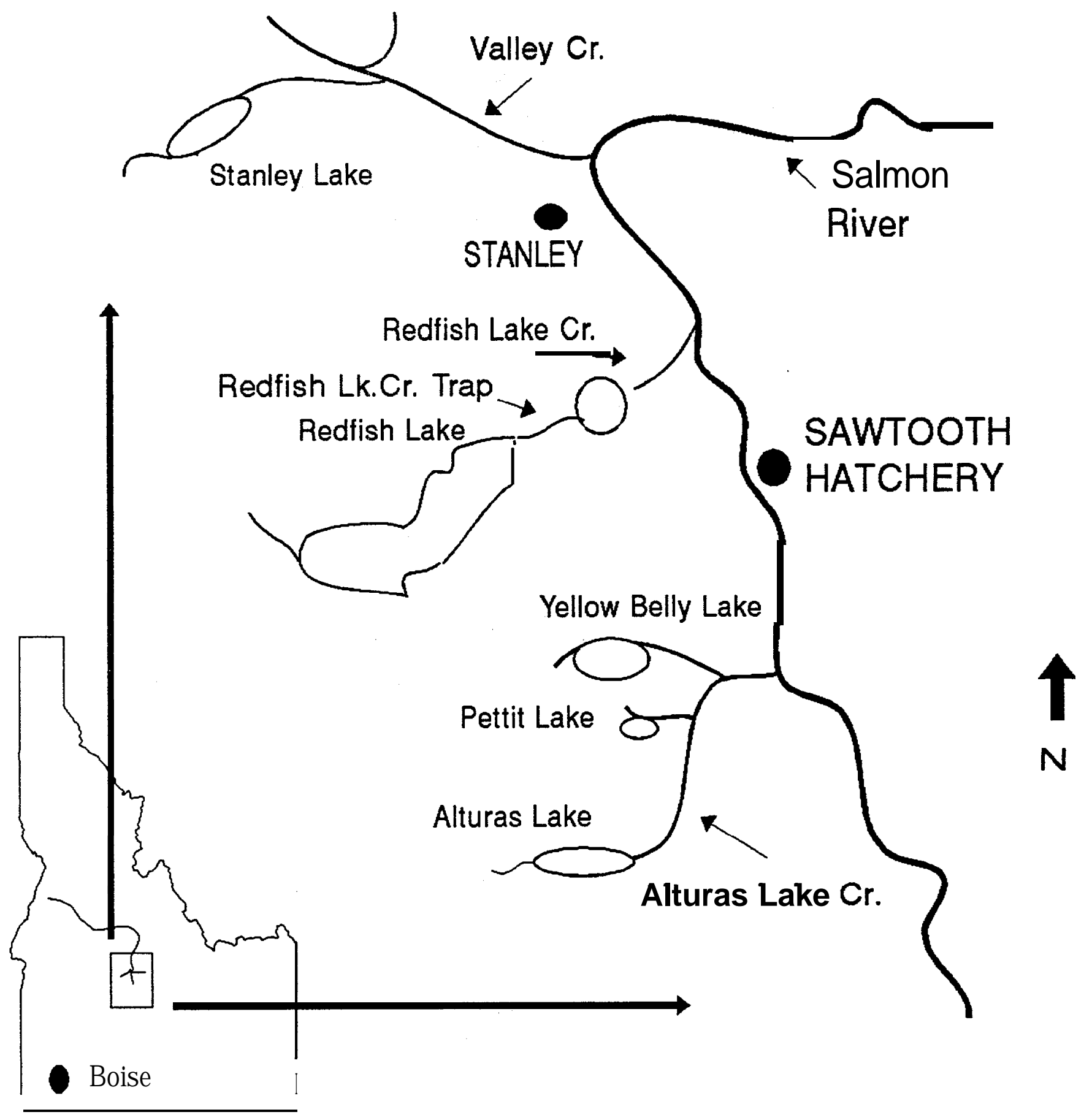

Figure 1. Stanley Basin map, Idaho. 
Table 1. Recent run sizes of sockeye salmon passing Lower Granite Dam.

\begin{tabular}{lc}
\hline Date & Number of fish \\
\hline 1982 & 211 \\
1983 & 122 \\
1984 & 49 \\
1985 & 35 \\
1986 & 15 \\
1987 & 29 \\
1988 & 23 \\
1989 & 2 \\
1990 & 1 \\
1991 & 8 \\
1992 & 1 \\
1993 & 12 \\
1994 & 2 \\
\hline
\end{tabular}

'Seen only at Ice Harbor Dam, Washington.

Table 2. List of existing facilities for incubating and rearing fish at Eagle Fish Hatchery.

\begin{tabular}{lccc}
\hline $\begin{array}{l}\text { Hatchery } \\
\text { rearing }\end{array}$ & $\begin{array}{c}\text { Unit } \\
\text { volume }\end{array}$ & $\begin{array}{c}\text { Number of } \\
\text { units }\end{array}$ & $\left.\begin{array}{c}\text { Construction } \\
\text { unit }\end{array} \mathrm{m}^{3}\right)^{3}$ \\
Incubator & NA & 1,370 & Plastic \\
R \& D & 0.09 & 48 & Fiberglass \\
1 Meter & 0.30 & 52 & Fiberglass \\
2 Meter & 1.42 & 34 & Fiberglass \\
3 Meter & 6.50 & 38 & Fiberglass \\
4 Meter & 8.89 & 4 & Fiberglass
\end{tabular}

${ }^{*}$ Multiple, small rearing units are used to satisfy program genetic goals.

\section{PURPOSE}

The purpose of the Eagle Fish Hatchery is to produce genetically-defined presmolts for restoration of Snake River sockeye salmon using captive broodstock technology. This program is designed to run for a single generation to limit the potential effects of long-term culture on the fitness of parental stock and progeny.

GOALS

Program goals are defined by the carrying capacity of receiving lakes within the critical habitat and by the genetic nature of indigenous sockeye salmon populations. At this time, progeny of captive broodfish have been released into Redfish and Pettit lakes of the Stanley Basin. Presmolts have been released directly into the lake or from net pens following a period of in-lake rearing at Redfish Lake. 


\section{O BJ ECTIVES}

1. Maintain broodstocks separately with identification of the genetic origin of individuals to maximize diversity and minimize inbreeding during spawning.

2. Define best management plans for Eagle Fish Hatchery to be used for recovery of listed. species.

3. Produce defined groups of progeny for evaluation of release strategies, appropriate size/time targets, and genetic origin to maximize smolt performance and adult return.

4. Apply principles from the Alaska Sockeye Salmon Culture Manual (1994) to reduce the risk of infectious disease interfering with attainment of program goals.

\section{Current Practices to Achieve These Objectives}

Fish Hatchery Production

1. All broodstocks originating from anadromous adults are duplicated at the NMFS Big Beef Creek facility in Washington state to guard against a single facility disaster. Progeny from the Big Beef Creek program are returned to Eagle Fish Hatchery only as iodophordisinfected eyed eggs.

2. Maintain rearing densities at or below $8 \mathrm{~kg} / \mathrm{m}^{3}$ at least through smolt size.

3. Fin-clip all production fish released to Stanley Basin lakes for identification purposes upon return as adults. Appropriate numbers of progeny are PIT-tagged for evaluation of smolt performance at migration.

4. All rearing units are kept in quarantine to prevent disease transfer.

5. Currently, up to 20 adults which return to the weir on Redfish Lake Creek may be used for hatchery broodstock. All adults in excess of 20 are to be released upstream for natural spawning.

Minimize Interactions with Other Fish Populations

Through Proper Rearing and Release Strategies

All returning anadromous adults have been taken into captivity since 1991. As a result, the only progeny in Redfish Lake with direct anadromous origin are the result of enhancement. There is a small population of "residual" sockeye salmon in Redfish Lake which continues to reproduce annually. Release strategies for progeny are designed to maximize migration of smolts and minimize residualization. Control efforts targeting the existing kokanee 0 . nerka kennerlyi population are to reduce competition with sockeye salmon possessing anadromous capability. Research into the best release strategy is on-going and deals with size/time and 
genetic origin of the presmolts. The goal is to allow for cultured fish to reside in Redfish Lake over winter and migrate volitionally in the spring.

Maintain Stock Integrity and Genetic Diversity

NMFS Propagation Permit \#795 requires that IDFG consult with NMFS annually to establish a spawning matrix for those groups expected to mature. The goal of this consultation is to evaluate how groups can be spawned to maximize diversity and minimize inbreeding with the limited genetic base available in this program. Each broodfish held in this program has been PIT-tagged and can be traced back to the origin of both parents. This is used to direct-mate selection and reduce the probability of inbreeding.

Management of Bacterial Kidney Disease in Broodstocks

Bacterial kidney disease Renibacterium salmoninarum(BKD) has been observed as a cause of death at Eagle Fish Hatchery in a single group of fish (OM91, Group 4; see Table 3 for broodstock definitions). This group was transferred to Sawtooth Fish Hatchery in 1993. BKD has been observed at Big Beef Creek in BY91, BY93, and OMBY93. The spawning of BY91 at Big Beef Creek and OM91 Group 4 at Sawtooth Fish Hatchery in 1994 created a risk of importing BKD to Eagle Fish Hatchery with the eggs originating from these broodstocks. IDFG proposed that all parents be screened for BKD using the enzyme-linked-immunosorbent-assay (ELISA) procedure and that only those eggs originating from parents with ELISA optical density (OD) values less than 0.2 be imported to Eagle Fish Hatchery. Eggs from parents with ELISA $O D$ values between 0.2 and 0.4 are to be reared at the station of origin.

\section{PERFORMANCE OF CULTURED GROUPS}

\section{Outmigrants 1991}

This group (OM91) has been cultured at Eagle Fish Hatchery since May $1991 . \quad$ Beginning inventory at Eagle Fish Hatchery for the reporting period was 178 fish averaging 2,148 g. There were an additional 40 similar-sized members of Group 4 at Sawtooth Fish Hatchery. The mean weight as of April 1995 was $3,000 \mathrm{~g}$ (Appendix A).

This group was part of a diet trial using a modification of the brood diet from Bioproducts, Inc. Three tanks at Eagle Fish Hatchery were fed a diet with $50 \%$ of the protein coming from Antarctic krill and containing selenium elevated above the $0.1 \mathrm{mg} / \mathrm{kg}$ of the normal brood diet. A fourth tank was fed the "regular" brood diet. The trial was conducted from March 31, 1994 through spawning. The results of the trial are reported in the section dealing with captive broodstock research. 
Table 3. Abbreviations used in the text.

The following abbreviations are employed throughout this report for the sake of brevity. Abbreviations are used for accuracy in describing the origin of stocks used in this recovery effort and are listed in chronological order.

\section{DESIGNATION PARENTAL, ORIGIN}

OM91 Obtained as outmigrants from Redfish Lake in April, May, and June 1991, cultured at Eagle Fish Hatchery from May 1991 until the present, and spawned in 1993 and 1994.

BY91 Obtained 'as eggs by spawning a single female and three male anadromous sockeye salmon which returned in 1991. These were divided between NMFS and IDFG as eggs and reared at Eagle, Montlake, and Big Beef Creek fish hatcheries. Maturation occurred in 1993 and 1994.

OM92 Outmigrants from Redfish Lake obtained in 1992 and cultured at Eagle to the present.

RESBY92 Progeny of three residual sockeye salmon seined from Redfish Lake in November 1992 and reared at Eagle until the present.

OM93 Outmigrants from Redfish Lake obtained in 1993 and cultured at Eagle to the present.

BY93 The progeny of the matings of two female and six male sockeye salmon which returned in 1993. The eggs were divided between Eagle and Big Beef Creek fish hatcheries. Those at Eagle were destined for broodstock and release, while those at Big Beef Creek were for broodstock only.

RESBY 93 Progeny of residual sockeye salmon seined from Redfish Lake in November 1993 and reared at Eagle until the present.

ANBY94 Progeny of a single female anadromous adult which returned to Redfish Lake in 1994. The eggs were divided between Eagle and Big Beef Creek fish hatcheries. Those at Eagle were destined for broodstock and release, while those at Big Beef Creek were for broodstock only.

BY94 The progeny of matings of captive broodstock at Eagle Fish Hatchery. These fish will be released into Redfish Lake $\left(N={ }^{-100,000)}\right.$ during the summer and fall of 1995.

Causes of mortality during the culture period were attributed to incomplete sexual maturity of females or maturation which occurred during the "off season." Ovaries of these females appeared to be atresic and contained eggs which appeared to be undergoing reabsorption. This condition was noted for 3 of 46 fish which died prior to the spawning period. Other causes included anoxia due to low water flow, culling non-maturing and 
deformed fish from the spawning population, handling during installation of gastric sonic tags, tumors, transport, fungus, and jumpouts. Twenty-four maturing fish of this group were released into Redfish Lake to evaluate volitional spawning.

The number of adults entering spawning was 106. The spawning matrix established with Dr. Robin Waples of NMFS was to use OM91 males to spawn with BY91 females. These fish were sorted to chilled $\left(10^{\circ} \mathrm{C}\right)$ water on September 14.

Sexual maturation occurred from October 2 through 27. Those fish which appeared to have a chance of maturing were held after January. Those which appeared not to have an opportunity of maturing or surviving were culled. The state of the gonads was recorded for all fish culled. The inventory for fish of this group remaining for spawning in 1995 is 44 fish. Table 4 gives the running total loss and causes for mortality of this group since beginning culture in 1991.

Only $30 \%$ of the adults which entered the spawning season successfully reached maturity. The relative success was better for males than females and the performance of gametes suggests males were able to progress to maturity more normally than females under the culture conditions at Eagle Fish Hatchery. It is probable that females require a longer exposure to chilled water than the few weeks that they were in 1994. If that is hypothesized to be the case, a longer exposure period will be provided in 1995.

The majority of females which were "culled" demonstrated coloration and morphological characteristics of maturation, but eggs failed to develop, were hard (water hardened), or had polarized yolk. This condition is rarely observed in wild females.

BKD management for OM91 Group 4 (Johnson 1992, 1993) involved feeding Erythromycin every other month and segregating this group at Sawtooth Fish Hatchery. Two females matured in 1993 and 13 adults matured in 1994. All were examined by ELISA for BKD with no values above the optical density of 0.10 . Additionally, 29 fish were culled from Group 4 following the spawning season of 1994 and these were also negative for BKD. Total specific loss to BKD for Group 4 was $45 \%$, and the disease was contained to this single group.

\section{Brood Year 1991}

Members of this group (BY91) are in their third year of culture at Eagle Fish Hatchery. Starting inventory for the period was 846 fish averaging 1,100 $\mathrm{g}$ while the final inventory in April 1995 was 104 fish averaging 2,600 g (Appendix A). Sexual maturation was the primary reason for this reduction ( $N=733$ fish). The schedule of maturation and spawning will be detailed later in this report.

The primary causes of mortality in this group were gill hyperplasia, cold water disease Flexibacter psychrophilus, stomach fluid accumulation, and mechanical causes (Table 4). Lymphosarcomas reported previously continue to be a cause of mortality (Johnson 1993; Johnson and Pravecek 1996).

The diet trial was also applied to these groups with $75 \%$ of the fish fed the "special" Biodiet brood diet and $25 \%$ fed the regular brood diet. The results are reported in the Captive Broodstock Research section of this report. 
Table 4. Summary of mortality for four groups of Redfish Lake sockeye salmon captive broodstocks from April 1991 to April 1995.

\begin{tabular}{|c|c|c|c|c|}
\hline & & Broo & oun & \\
\hline & OM91 & BY91 & OM97 & OM93 \\
\hline $\begin{array}{l}\text { Starting Number } \\
\text { Time in Culture }\end{array}$ & $\begin{array}{c}861 \\
5 / 91-4 / 95\end{array}$ & $\begin{array}{c}937 \\
1 / 92-4 / 95\end{array}$ & $\begin{array}{c}79 \\
5 / 92-4 / 95\end{array}$ & $\begin{array}{c}48 \\
5 / 93-4 / 95\end{array}$ \\
\hline Loss Type: & & & & \\
\hline Mistakes & & & & \\
\hline Transport & 226 & 13 & & \\
\hline Dewater & 113 & 10 & & 25 \\
\hline Trapping & 61 & & & 4 \\
\hline Handling & 59 & & & \\
\hline Jump-out & 13 & 5 & 1 & 2 \\
\hline Total & $\overline{472}$ & 28 & 5 & 27 \\
\hline$\%$ & 54.8 & 3.0 & 6.3 & 56.3 \\
\hline Non-infectious & & & & \\
\hline Tumors & & 14 & 6 & 1 \\
\hline Pin Head & & 3 & 5 & 4 \\
\hline Stomach Fluid & 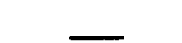 & 32 & & \\
\hline Total & 17 & 43 & 5 & 0 \\
\hline$\%$ & 1.9 & 4.6 & 6.3 & 0 \\
\hline Infectious & & & & \\
\hline BKD & & 96 & & \\
\hline Undetermined & 30 & 24 & 16 & \\
\hline Gill Disease & 27 & 3 & 4 & \\
\hline Aeromonads & 19 & 6 & & \\
\hline Fungus & & 11 & 3 & 5 \\
\hline Flexibacter & 8 & 16 & & \\
\hline Loma & & 2 & & \\
\hline Entercytozoa & & & & 1 \\
\hline Nephroca lcinosis & & 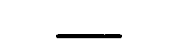 & 3 & - \\
\hline Total & 193 & 52 & 29 & 0 \\
\hline$\%$ & 22.4 & 5.6 & 36.7 & 0 \\
\hline Maturation & & & & \\
\hline Spawned & & 76 & 594 & 6 \\
\hline Undeveloped & 73 & 37 & & \\
\hline Prespawn loss & 8 & 37 & & 2 \\
\hline Green & & 1 & 4 & \\
\hline Cull 1195 & 11 & 15 & & \\
\hline Late maturing & & 3 & 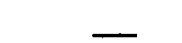 & \\
\hline Total & 169 & 690 & 6 & 2 \\
\hline$\%$ & 19.6 & 73.6 & 8.3 & 4.2 \\
\hline Alive $4 / 95$ & 44 & 104 & 34 & 20 \\
\hline
\end{tabular}




\section{Outmigrants 1992}

This broodstock (OM92) was started from 79 outmigrating smolts captured at the Redfish Lake Creek trap in 1992 and is in their third year of culture. The starting inventory for the report period was 69 fish averaging $990 \mathrm{~g}$ and finished with 34 fish averaging 2,300 $\mathrm{g}$ (Appendix A). Only six of the 25 fish which died in 1994-I 995 had matured. Causes of death included fungus, stomach fluid accumulation, one lymphosarcoma, nephrocalcinosis, and one case of Entercytozoa salmonis (Table 4). The latter two causes represent the first occurrences of these untreatable diseases in sockeye salmon broodstocks at Eagle Fish Hatchery.

\section{Outmigri ts 1993}

This broodstock (OM93) was started from 48 outmigrants captured at the Redfish Lake Creek trap in 1993. The fish averaged $8.9 \mathrm{~g}$ upon arrival and grew to $1,300 \mathrm{~g}$ by April 1995 (Appendix A). A mistake during tank cleaning caused the loss of 25 fish (Table 4). Ending inventory in April 1994 was 20 fish.

\section{Residual Broed Year 1992}

This broodstock (RESBY92) was started from a single, wild, Redfish Lake, "spawnedout" residual female from which 36 eggs were obtained. Eggs were fertilized with sperm from two wild residual males. The starting inventory in April 1994 was 35 fish averaging $175 \mathrm{~g}$. Currently, there are 14 fish averaging $900 \mathrm{~g}$ (Appendix A). Twenty-one males matured in October and, because there were no mature residual females, were returned to Redfish Lake to spawn volitionally. This is the first time at Eagle Fish Hatchery that such a high percentage of males matured precociously at two years of age. The mature residual males averaged 500 $g$ in weight.

\section{Anadromous Brood Year 1993}

The progeny (ANBY93) of the two female and six male anadromous sockeye salmon which returned in 1993 were ponded at Eagle Fish Hatchery in February 1994. Equal numbers $(N=35)$ of each sub-family $(N=12)$ were retained for broodstock. The remaining 1,610 progeny were adipose fin-clipped for release into net pens in Redfish Lake. A sample of 850 fish were also PIT-tagged. Releases from the net pens were made in August due to higher than anticipated water temperatures. Seaward migration is expected in the spring of 1995.

Those selected for broodstock were placed on two growth rates in an attempt to produce two classes of age at maturity. This was based on the observation from many captive broodstocks, including Snake River sockeye salmon, that larger fish mature at a younger age. Currently, there are 275 fish averaging $205 \mathrm{~g}$ for the "normal" growth group, 275 fish at 150 $\mathrm{g}$ in the group with the "slower" rate of growth, and 180 fish destined for release below the Redfish Lake Creek weir in April 1995 (Appendix A). All fish were PIT-tagged and all fish 
destined for release were adipose fin-clipped. Survival within this group has been excellent, with most mortality due to mechanical causes.

\section{Outmigrants Brood Year 1993}

These progeny (OMBY93) were the result of spawning OM91 females which matured in October 1993 with the six anadromous males of 1993. Most $(N=9,520)$ were released into Redfish Lake in 1994. Current inventory of the OMBY93 broodstock includes 109 fish averaging $165 \mathrm{~g}$ and an additional 350 destined for release in April 1995 (Appendix A). Most mortality was due to mechanical causes, although some cold water disease was detected in this group. All released fish were PIT-tagged and adipose fin-clipped.

\section{Residual Brood Year 1993}

In October 1993, two residual females were spawned with four males to produce subfamilies (RESBY93). The eggs from one female in this spawning failed to hatch. Twenty-eight fish were raised to a size of $180 \mathrm{~g}$ by April 1995 (Appendix A). Causes of mortality were mechanical and external fungus.

\section{Brood Year 1993.5}

Progeny of BY91 adults which matured off-season (Appendix B) were given this designation (BY93.5) to differentiate them from progeny of spawnings made in the normal time window of October 1993 or 1994 . The parents originated from the October 21, 1991 spawning of a single anadromous female crossed with three anadromous males. All maturation occurred with the normal photoperiod of Eagle, Idaho ( $44^{\circ}$ North latitude) on ambient water temperatures employed during this period. All progeny were to be released into Redfish Lake because of the unusual time of spawning. These groups were reared for release directly into the lake in November 1994 or directly below the smolt weir on Redfish Lake Creek in April 1995.

\section{Brood Year 1994}

Brood year 1994 was the start of spawning activities at Eagle Fish Hatchery in which chilled water was available. The protocols for spawning these broodstocks (BY94) directed that out-crosses be made between generations to reduce the effects of inbreeding. The general spawning protocol called for dividing the eggs from each female into four lots. One male fertilized two sub-lots and a second male fertilized the remaining two sub-lots. Incubation was done at $10^{\circ} \mathrm{C}$ for the first $48 \mathrm{~h}$ for all egg lots. After $48 \mathrm{~h}$, one lot from each male was moved onto water chilled to $5^{\circ} \mathrm{C}$ until ponded. Exceeding the capacity of the water chiller caused the lower incubation temperature to vary. This split in incubation temperature was employed to slow the development of a portion of the eggs. The use of two incubation temperatures resulted in two different rates of development for groups of similar genetic origin allowing 
releases at two different size/time targets. This is important in assuring that comparisons of different release strategies do not become affected by the different genetic origins of the parents or by fish size.

Ponding was done to enable tracking of parental genetic type into three types: BY91 x OM91 or 92, BY91 x BY91 (half siblings) originating from Eagle Fish Hatchery and BY91 x BY91 originating from Big Beef Creek at two levels of BKD titer in parents (see BKD policy). The goal will be to retain these designations separate until PIT tagging to evaluate the relative performance of each genetic type within the three release strategies. All fish for release of BY94 will be adipose fin-clipped and a representative number also PIT-tagged.

Releases are planned for 1995 into Redfish Lake under the following release strategies:

1. Late June direct release at a projected size of $5 \mathrm{~g}$.

2. Placed into net pens in Redfish Lake, reared through the summer, and released in October at a projected size of $10 \mathrm{~g}$.

3. Direct release of $10 \mathrm{~g}$ fish in October.

\section{Anadromous Brood Year 1994}

This group designation (ANBY94) pertains to the progeny of spawning a single anadromous female which returned in 1994 with captive broodstock males of BY91 subfamilies $A, B$, and $C$ and two males of OM91. Sub-families have been kept separate through April 1995. Incubation was done at $10^{\circ} \mathrm{C}$ because these groups were comprised of only 450 eggs per sub-family and were to be kept separate until the fish could be PIT-tagged (target size of $7 \mathrm{~g}$ ). The proposal is to retain 450 progeny for brood and release the excess. This will be the only broodstock retained at Eagle Fish Hatchery of this brood year.

\section{ADULT TRAPPING AT REDFISH LAKE CREEK}

The adult weir was installed and operated from June 25 through October 15, 1994. A single female anadromous sockeye salmon was trapped on August 17. The fish was transported to Sawtooth Fish Hatchery and held on $10^{\circ} \mathrm{C}$ well water until September 25, when she was transported to Eagle Fish Hatchery and held with OM92 cohorts until mature. Details of the spawning protocol are given in the Anadromous Brood Year 1994 section. The carcass was sampled for pathology, genetics, otoliths, and meristics. After sampling, the carcass was incinerated. 
SPAWNING ACTIVITIES FOR 1994

\section{Spawning Matri d Genetic Identity of Broodstocks}

Several investigations related to the genetic make-up of sockeye salmon captive broodstocks funded by BPA are reported to the Snake River Sockeye Technical Oversight Committee. Studies by Brannon (1994) have shown the genetic relationships of the sockeye salmon and kokanee of Redfish Lake and how these relate to captive outmigrant broodstocks. The original goal of these studies was to investigate whether the captured outmigrants represent sockeye salmon or kokanee genetics. All results have demonstrated that the Redfish Lake outmigrants collected in 1991, 1992, and 1993 have a close or identical genetic relationship with the Redfish Lake sockeye salmon genetic type and there is no or very low relationship to Fishhook Creek kokanee.

The adipose fin of each member of the outmigrant broodstocks was removed and coded by the PIT tag number. DNA analyses were performed by Dr. Ernest Brannon at the University of Idaho. These results were used when the proposed spawning matrix was established. Essentially, the DNA data show that we did not have to be concerned with kokanee genetics in the spawning of outmigrant broodstocks.

\section{Timing of Maturation in 1994}

Maturing fish were observed in nearly every month of 1994, although the majority occurred during the expected October-November time period (Figure 2). The maturity schedule in Figure 2 includes maturity in the fall of 1993 for perspective. "Off season" maturity accounted for about $15 \%$ of total maturity for 1994 and included adults from BY91.OM91. and OM92 broodstocks. Usually there were males available to donate sperm for attempted matings, although Gonadotropin Releasing Hormone $(\mathrm{GnRH})$ was used to try to synchronize maturity. Males were often used repeatedly for these "off season" matings.

Males of RESBY92 matured in October 1994. This maturation of 2-year-old males was observed in 1993 in BY91, but at a much reduced rate. A total of 21 males were removed from a total population of 34. Because these fish were destined to be mated only with other residuals and none were available, fish were returned to Redfish Lake for volitional spawning (Kline 1995).

\section{General Spawnin rotocol}

The spawning protocol employed for 1994 was similar to those used previously with captive broodstocks (Johnson 1993; Johnson and Pravecek 1996). The goal has been to use two males per female but to allow for identification of the formed sub-families with the pathology samples taken from each spawner. Genetics samples and otoliths were also taken from appropriate OM91 and OM92 spawners. 


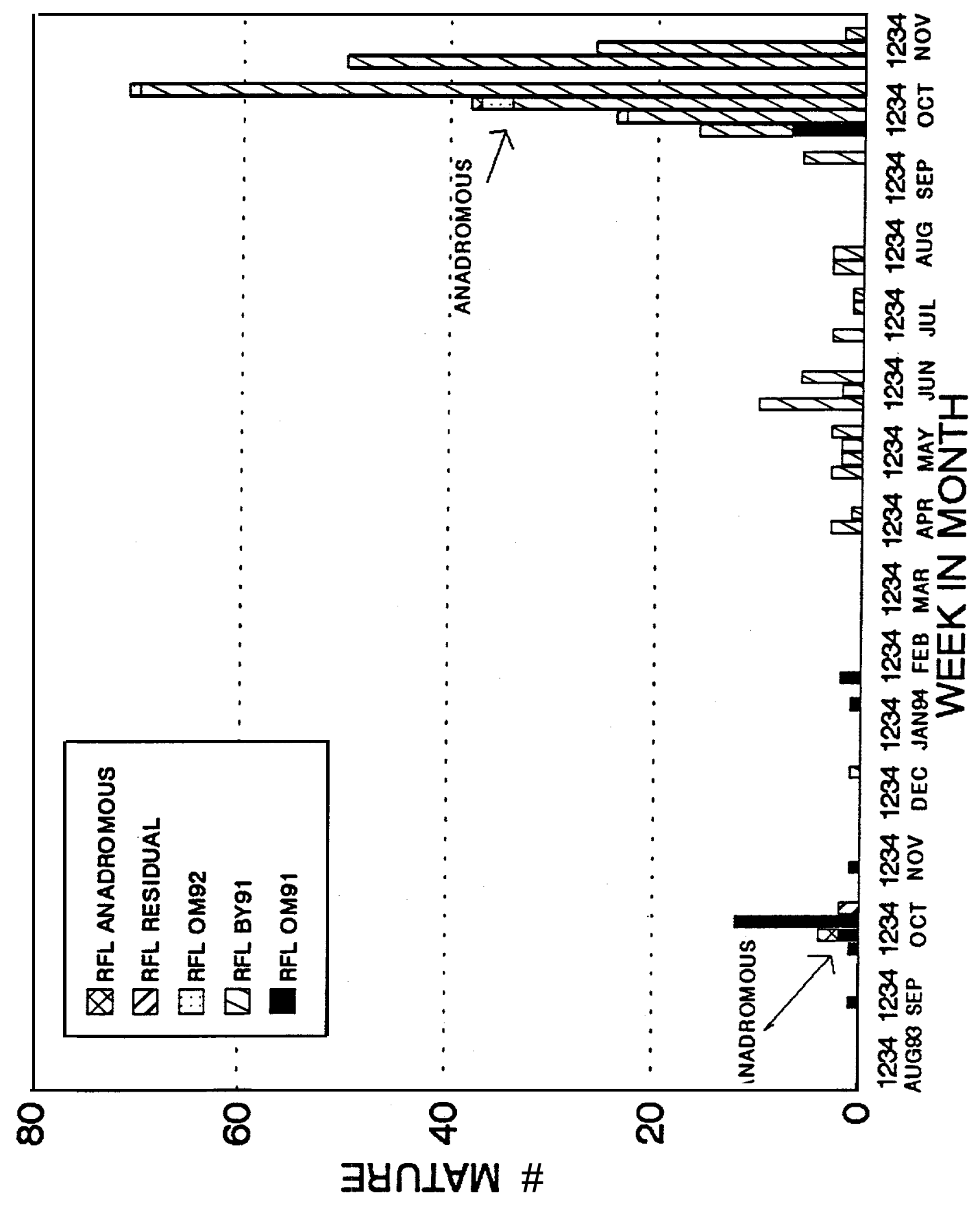

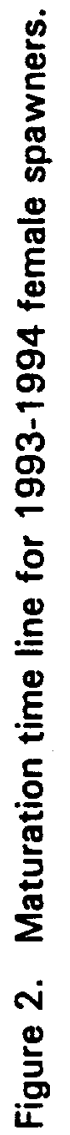


Sperm motility was assessed for milt samples from each male each time it was used. Eggs were divided into four equal lots by weight. Milt from each male was used to fertilize two egg lots. Fertilization was accomplished by the addition of $10^{\circ} \mathrm{C}$ hatchery water, $0.85 \%$ saline, or Theophylline-Tris activator and the mixture allowed to set for $2 \mathrm{~min}$. Excess sperm was decanted and replaced with $100 \mathrm{mg} / \mathrm{l}$ iodine as Argentyne. After $\mathbf{2 0} \mathrm{min}$, eggs were loaded into incubators. Incubation was initiated at $10^{\circ} \mathrm{C}$ for $48 \mathrm{~h}$ for the four egg lots. After $48 \mathrm{~h}$, two egg lots (one from each male) were transferred to the lower incubation water temperature (generally $5^{\circ} \mathrm{C}$ ). This protocol was followed to yield two identical genetic groups incubating at two rates to coincide with the anticipated release strategy. This approach allowed evaluation of fertilization rates of eggs from each female with sperm from two separate males (Le., evaluate whether poor fertilization originated from egg or sperm quality problems).

\section{"Off Season" Matings - April to Auqust 1994}

A total of 41 BY91 females matured during this period while 5 males of both BY91 and OM91 origin matured. The shortage of males resulted in mature males being used multiple times. In addition, cryopreserved sperm from four residual males was used to supplement fresh sperm. Table 5 summarizes the data from crosses made during the April to August period. Fertilization was generally very poor with a range from $0 \%$ to $97 \%$. No fertilization was obtained with the eggs of 18 of the 41 females (44\%). During the course of this spawning period, attempts were made to improve fertilization. The major impediments to evaluating these attempts were: 1) chilled water was not available, and 2) fertilization was dependent on egg quality. We attempted to chill gametes prior to fertilization which had no apparent affect on the resulting fertilization. We used hatchery water, $0.85 \%$ saline, or activator as fertilization media without apparent change in fertilization. Nearly all matings made with cryopreserved sperm proved to be infertile, although these milt samples fertilized fresh kokanee eggs when tested after freezing.

Three spawnings in May were done with both cryopreserved and fresh sperm with eggs from the same female. Eyed eggs were obtained with crosses made with cryopreserved sperm of residual males MI, M6, and M9, but no eyed eggs were obtained from egg lots fertilized with M9. Fresh milt performed better than cryopreserved milt. We were unable to demonstrate improved fertilization with $0.85 \%$ saline, but it appeared that activator may have given higher motility values and therefore its use was continued.

\section{Spermatozea Quality Estimation}

Throughout the spawning period of April through August, we attempted to improve the rate of fertilization of eggs. Several evaluations were made to examine whether sperm quality was causing the low fertilization and whether improvements could be made. Historically, estimations of sperm quality have focused on spermatozoa motility in several fertilization media, percent packed cell volume (pcv), duration of motility, and spermatozoa viability. Five males were used repeatedly from May to August and sperm quality parameters were evaluated for these males throughout the period. Males were involved in the on-going diet study to test for diet effects also. 
Table 5. Results of spawnings made with Redfish Lake sockeye salmon captive broodstocks at Eagle Fish Hatchery from April through August 1994.

\begin{tabular}{lcccc}
\hline Month & FM $(\mathrm{N})$ & No Viab/Total & \% Eyed Range & \% Ponded Range \\
April & & & & \\
May & 4 & $4 / 4$ & $11-17$ & $0.5-15$ \\
June & 10 & $4 / 10$ & $3-96$ & $1.7-100$ \\
July & 16 & $12 / 16$ & $1-97$ & $8-75$ \\
August & 3 & $1 / 3$ & 5 & 0 \\
& 4 & $4 / 8$ & $3-27$ & $0-25$
\end{tabular}

'Number of females from which eyedeggs were obtained divided by total spawned for month.

Egg quality from captive females was too poor for fertilization. Therefore, fertilization could not be used as a reliable parameter for comparison. The method of sperm collection had a primary effect on motility, pcv, and viability. Once samples were taken from the bags to be used for fertilization and not expressed first, all quality parameters being measured improved dramatically. This became the standard method of collection.

There was no apparent relationship between motility and fertilization during this period. Also, there was no effect of using the special brood diet on sperm quality. The early methods of sperm collection may have masked an effect. Generally, milt was used from males only if motility estimates were $70 \%$ or above and activator was used as the fertilization medium because motility estimates were usually highest with its use. Viability estimates were discontinued when it became apparent that these data were not yielding useful information. The conclusion from the evaluation of sperm quality was that poor egg quality was the primary cause of infertile eggs.

\section{Spawningi 11994}

Chilled water became available at Eagle Fish Hatchery on September 14, 1994. Temperature for broodstock tanks was set at $10^{\circ} \mathrm{C}$. Adults showing signs of sexual maturity were selected from each group held at $13^{\circ} \mathrm{C}$ (ambient) water and moved to the colder water. Mature fish of both sexes were mixed, while broodstocks and treatments were kept separate. This allowed for rapid selection of mated pairs based on OM versus BY origin, year of OM capture, and diet fed. The first selection of mature adults was completed in two days. After this, maturing adults were separated on a weekly basis and sorted for ripeness twice weekly. Holding tanks were $4 \mathrm{~m}$ in diameter, while those used for final holding were either $4 \mathrm{~m}$ or $2 \mathrm{~m}$ tanks depending on anticipated number of maturing adults.

The spawning matrix established between NMFS and IDFG was used to direct mate selection whenever possible. Circumstances in which this was not possible included where no males of an appropriate group were available or sperm motility estimates were less than $70 \%$.

The generalized spawning protocol previously described was followed during the fall spawning period. All fish used for gametes were also sampled for length, weight, pathology, otoliths, and genetics (protein electrophoresis and DNA) using bar code labels to identify each sample. Each sub-family of eggs was also identified with the bar code from each male and 
female which contributed to the mating. These labels were kept on the incubators for the duration of incubation and used to track the genetic types when fry were ponded.

Pathology samples included ovarian fluid (OF), kidney/spleen for viral examination, and kidney samples for BKD by ELISA. Disease analysis was conducted on site at the IDFG Eagle Fish Health Laboratory.

For a complete review of female performance see Table 12 and Table 13 in the Captive Broodstock Research section. Appendix B lists proportions of progeny for BY94 by genetic type.

If the eggs from a female appeared drastically abnormal, fertilization was not attempted and the eggs were discarded. Prior experience has shown that eggs displaying these features (i.e., polarized yolk or severe variation in egg size) do not fertilize. Females were selected for spawning using the usual combination of sexual dimorphism, coloration, behavior, and distribution of "spongy" texture to the posterior abdominal cavity. This combination of features resulted in an accumulation of females in the holding tanks which did not contain quality eggs. This may have been due to the criteria used for sorting and not due to a progression of this maturation disorder.

\section{Timin of Maturity}

Figure 2 depicts the timing of maturation for females during October 1993 through November 1994. It illustrates the proportion of females of each broodstock which matured by month covering BY93, BY93.5, and BY94. The anadromous females for both years $(N=3)$ matured during the expected time window, as did those of outmigrant origin, except the three which matured in January and February 1994.

Time of maturity is considered a highly heritable characteristic in salmonids (Hard and Hershberger 1995). Interestingly, BY91 fish were the result of spawning a single female with 3 males on October 21, 1991, and yet the timing of maturity encompassed two normal timing periods and also the April through August period (Johnson 1992). There are over 100 fish, representing $11 \%$ of the original population, which have yet to mature. This abnormal event of "off peak" spawning illustrates the need to account for culture conditions such as water temperature, lack of latitude change in nonmigratory holding conditions, diet, etc., other than genetics as contributors to timing of maturation. It also illustrates the high degree of variability which is not solely explained by genetic origin.

Maturation of females shown by week during the normal spawning period is shown in Figure 3, along with the proportion of females whose eggs failed to fertilize. As mentioned previously, infertile females probably accumulated toward the later part of the spawning period. The peak two-week interval of successful maturity was from October 20 through November 3. This coincides with the expected maturation time for Redfish Lake sockeye salmon and the timing observed at Big Beef Creek (Flagg 1994).

The percent fertilization (percent eyed eggs) by spawning date (Figure 4) illustrates that there was an optimum window for fertilization which preceded the maturation peak and may be more closely related to the use of OM91 and OM92 males rather than BY91 males (half- 


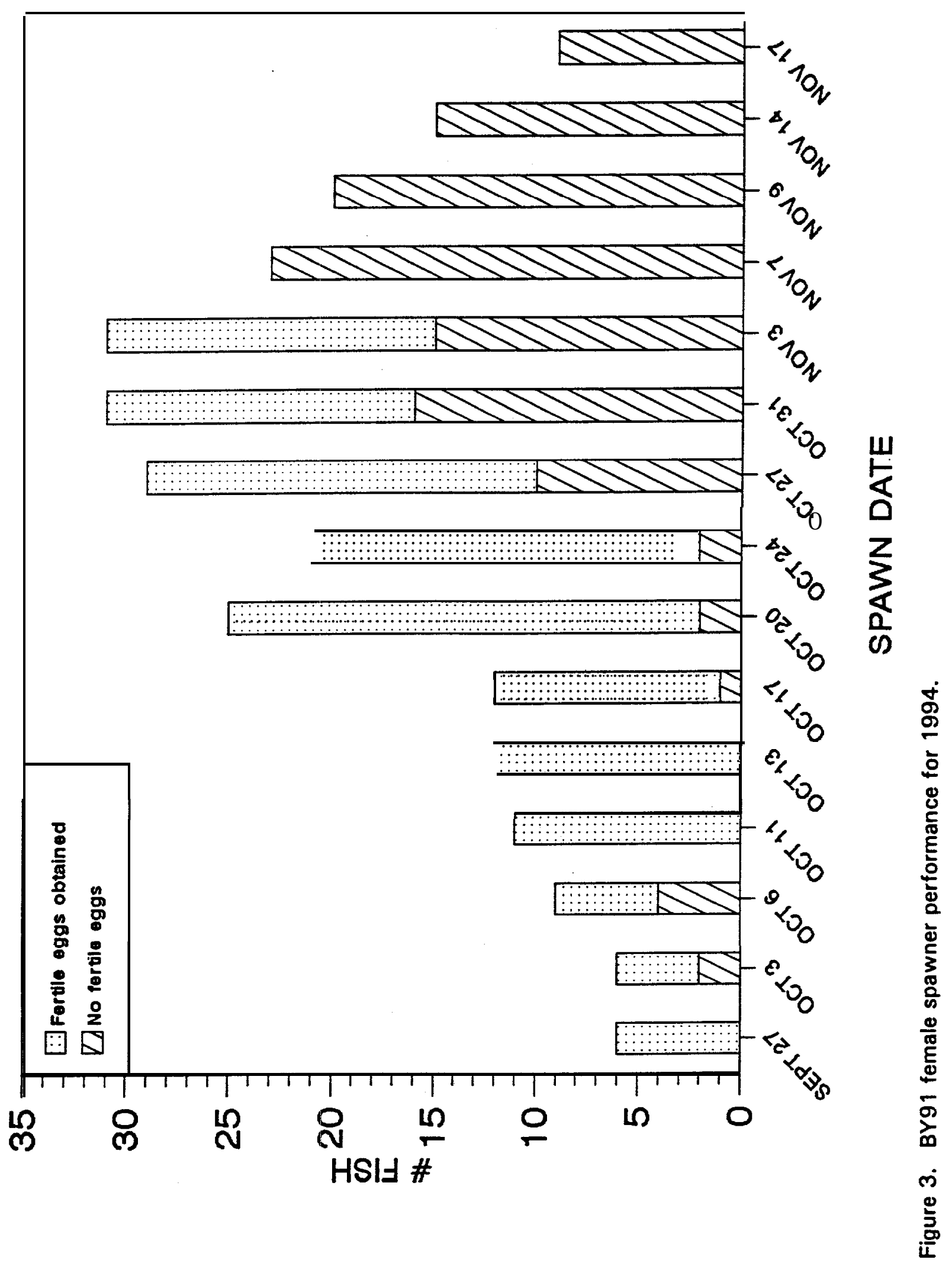




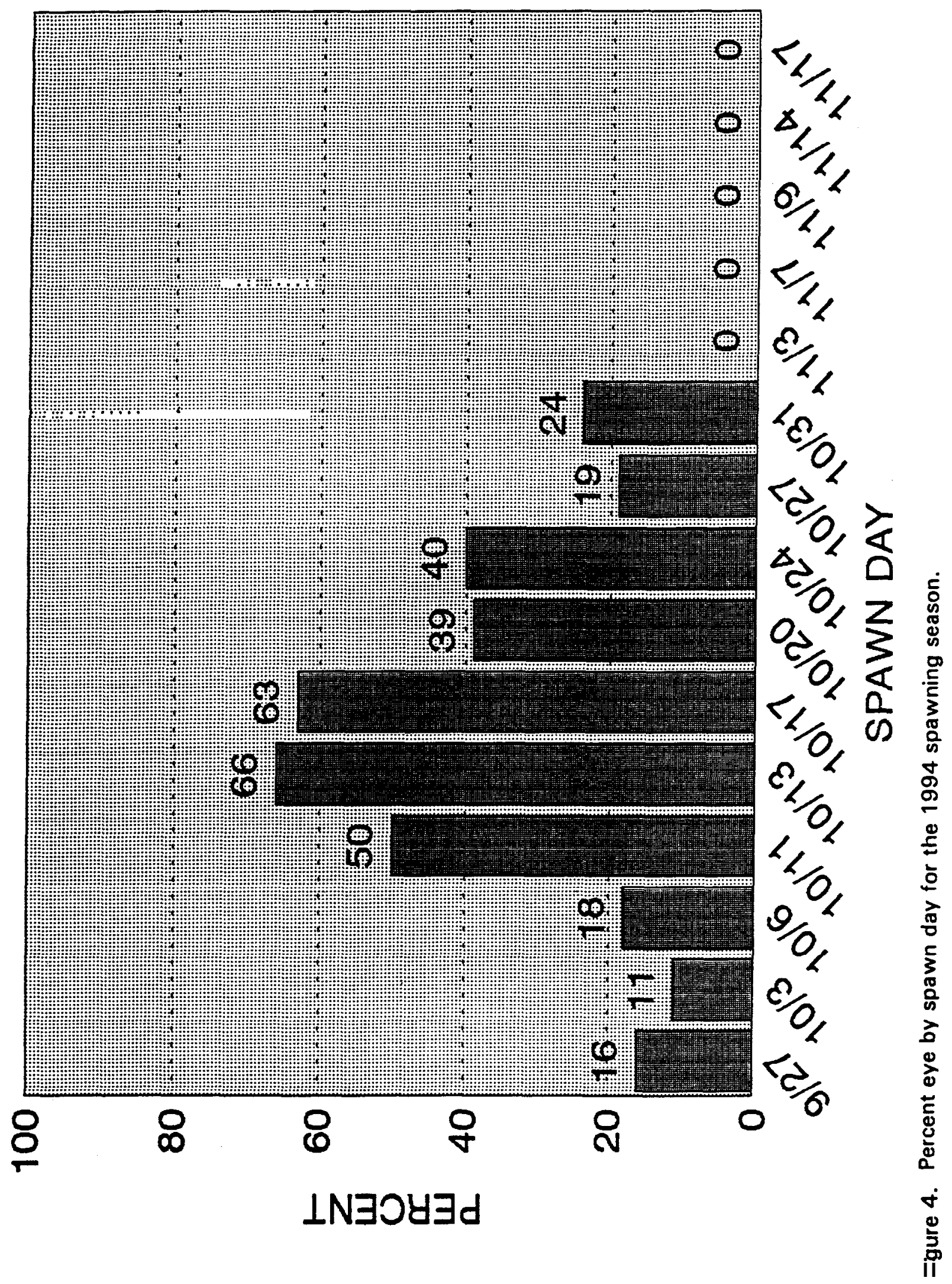


sibling matings). This was not observed with the spawning crosses made at Big Beef Creek, since all those crosses were made as half-sibling matings.

\section{Percent Fertilization}

The highest percent fertilization did not appear to be related to sperm quality parameters due to an abundance of high quality sperm. OM91 and OM92 males were used repeatedly during this spawning period since they were preferred in forming out-crosses. We should not have released as many OM91 and OM92 males for volitional spawning as this also contributed to a paucity of males for out-cross matings. Males of these groups were mostly exhausted by the peak of spawning. See Table 12 and Table 13 for a more detailed account of fertilization for BY94.

\section{Potential for Inbreeding}

Appendix B shows the number of different males and females of each genetic type which contributed to viable offspring of BY94. Acknowledging that we cannot determine the number of parents which contribute to outmigrant or residual broodstocks, this information should be tracked for each generation of progeny to estimate the degree of inbreeding (Hard and Hershberger, 1995). We entered this broodstock program fully aware that the limited number of adults which were available for recovery was below the generally accepted minimum population threshold $\left(\mathrm{N}_{\mathrm{o}}\right)$.

\section{Cryopreservation of Sperm}

Sperm of BY91 origin was harvested on two dates for cryopreservation. The goal was to preserve a large quantity of each sub-family type for use in future years. Sperm from 15 males was harvested and shipped to the laboratories of Dr. Joe Cloud, University of Idaho and Dr. Gary Thorgaard, Washington State University (WSU). About $10 \mathrm{ml}$ of sperm was harvested from each male and an oxygen atmosphere was added prior to closing the sample bag. Samples were shipped on ice and received within $4 \mathrm{~h}$ of harvest.

Quality control of cryopreserved sperm was done by using a sample of the frozen straws to fertilize fresh kokanee eggs obtained on December 23, 1994 from the IDFG Cabinet Gorge Fish Hatchery. Fresh sperm served as a control. Incubation was taken to the eyed stage and the percent fertile eggs was determined. The eye-up rate for control groups at the two laboratories was $69 \%$ for WSU and $46 \%$ for the University of Idaho. Fertilization rates varied from a low of $50 \%$ of control to a high of $99 \%$ of control for straws frozen at WSU. Results were similar for straws frozen at the University of Idaho, although there was a lower absolute fertilization rate which was also reflected in the controls. Generally, fertilization rates with the sperm harvested in 1994 were higher than experienced in previous years (Johnson 1992, 1993). Workers at both laboratories felt that the sperm quality was better this year. This was probably due to the abundance of males and being able to discard poor milt harvests containing urine (McNeil and Bailey 1975). 


\begin{abstract}
Adults
Sixty-three adult fish were selected for release into Redfish Lake in 1994. Releases were made in August, September, and October and included fish of BY91,OM91, and RES92 origin. All released fish were PIT-tagged and a portion of the groups implanted with ultrasonic tags. Tracking of the released fish will be reported by Kline (1995). Information on dates, fish numbers, and fish origin can be found in Appendix $\mathrm{C}$.
\end{abstract}

\title{
Release Strategies for Juvenile Sockeye Saimon
}

Three methods of rearing and releasing progeny resulting from spawning of the Redfish Lake sockeye salmon captive broodstock were considered to have the greatest potential of returning anadromous adults. These were derived from sockeye salmon culture experiences in Alaska, British Columbia, and Washington as reported in the AlaskaSockeve Culture Workshop proceedings (1985-I 9931. Methods included rearing presmolts in net pens until the fall turnover, a direct release in the fall of presmolt-sized fish, or a direct release of smolts downstream of the smolt evaluation weir in spring 1995. Fish used in the third release were those of ANBY93, OMBY93, and BY91BY93.5 origin.

\section{Net Pen Culture}

The primary goal of using net pens was to duplicate successes with sockeye salmon culture obtained elsewhere in which fish were grown during summer months and released in the fall. It is felt that fish grown under this strategy learn to forage for natural prey and elect to emigrate at their preferred timing.

A net pen complex was borrowed from NMFS, installed in Redfish Lake, and fish were reared in it during July 1994. Water quality parameters were monitored at least three times weekly. The SBSTOC directed that if water temperatures exceeded $14^{\circ} \mathrm{C}$ at a depth of $12 \mathrm{~m}$, fish would be released from the pens rather than continue holding them under adverse temperature conditions. The unusually hot summer combined with a low run-off year resulted in the groups being released on August 4, 1994. Releases by genetic cross are as follows: BY $x$ BY $(N=152) ; A N \times A N(N=1,610) ; O M \times A N(N=9,337)$; OM $\times$ OM $(N=31)$.

\section{Eall Dir Release}

Spawnings from the captive broodstocks made during April-June 1994 resulted in 2,989 presmolt-sized progeny of BY $x$ BY origin. Fish were released at the boat ramp of Redfish Lake on November 23, 1994. All fish were adipose fin-clipped and representative numbers PITtagged. 


\title{
Spring Direct Release
}

Three groups of progeny from BY93 and BY93.5 were released below the smolt trap on April 21, 1995. These groups are included in this report because they should contribute to the 1995 migration year. Rearing of groups of BY93 could not continue at Eagle Fish Hatchery because of space restraints caused by the spawning of the anadromous female which returned in 1994. Members of BY93 were considerably larger than normal for smolts since they had been reared at Eagle Fish Hatchery under a rearing protocol for broodstock. Fish were about $180 \mathrm{~g}$ in weight and had comparable genetics to those released into the lake from net pens in August $1994(\mathrm{~N}=518)$. The relative outmigration performance of these groups should provide a size/time comparison. The third group was fish which resulted from spawnings of the BY91 captive broodstock during July $1994(N=3,277)$. The release site selected was downstream of the smolt trap in an attempt to discourage residualization.

\section{CULTURE OF BROOD YEAR 1994}

\author{
Incubation
}

The spawning protocol resulted in $50 \%$ of the eggs being incubated at $5{ }^{\circ} \mathrm{C}$ and $50 \%$ at $10^{\circ} \mathrm{C}$. Two release strategies would be followed with the goal of half of each genetic type being released from net pens and half in a direct release in the fall. This was changed at the January 1995 SBTOC meeting to include three release groups: June direct release; October net pen release; and October direct release. Approximately $20 \%$ of the $5^{\circ} \mathrm{C}$ groups were shifted to a higher incubation temperature to accommodate the new strategy. After this was done, later egg lots were shifted to slightly warmer incubation temperatures in order to have feeding commence at approximately the same date for each of the lots in each of the three rearing strategies.

The exception to the above was the ANBY94 groups. These fish were incubated and reared on $10^{\circ} \mathrm{C}$ water since the groups were too small to divide. The four genetic groups of ANBY94 will be reared separately until they can be PIT-tagged and members divided into broodstock groups and release groups. feeding.

Once fry began to swim-up, feed was given in the incubators for several days to initiate

\section{Egg Lots Received from NMFS}

Eggs were received from Big Beef Creek by airfreight on December 4, 1994. These were placed into quarantine incubation at Eagle Fish Hatchery in eight groups by ELISA titer. Groups will be maintained separately until the samples are taken to determine if the progeny satisfy the 0.2 ELISA OD criterion. These progeny currently number 18,000 and represent $20 \%$ of the BY94 progeny destined for release in 1995. 


\section{Ery Culture}

Poor success in fertilization at Eagle Fish Hatchery resulted in approximately 100,000 BY94 progeny being ponded. Most of the loss beyond the eyed stage resulted from deformities after hatching. These included, in order of descending frequency: backs reflexed foreword, pinched bodies - especially posterior of the body cavity, shriveled peduncles, Siamese twins joined at the body cavity, Siamese twins joined at the vertebral column, and distended yolk sacks filled with fluid. The estimated prevalence was $6 \%$ and was higher than normally observed for other cultured salmonids.

Three genetic types were generated from the spawnings for BY94. These included progeny from the anadromous female mated with BY91 males and OM91 males (ANBY94); progeny from matings of BY91 females mated with OM91 and OM92 males or OM females mated with BY91 males (BYOMBY94); and progeny from matings of BY91 females and BY91 males (BY91BY94). These groups were divided into the release groups. Groups are being reared separately until the time of PIT tagging to allow evaluation of the relative outmigration performance of each genetic type within each release strategy. Growth has been adjusted to have the net pen group and the fall direct release group at a similar size in October 1995.

\section{CAPTIVE BROODSTOCK RESEARCH}

Historically, large numbers of adult sockeye salmon were reported making the nearly $1,500 \mathrm{~km}$ journey from the ocean to the Stanley Basin lakes of central Idaho. By 1986, Redfish Lake was the only lake in the basin which still supported runs of Snake River sockeye salmon. In December 1991, as a result of only six fish returning to Redfish Lake during the previous three years, NMFS declared the Snake River sockeye salmon "endangered" under the Endangered Species Act (ESA) of 1973.

Initial efforts to recover the species include the establishment of a captive broodstock at Eagle Fish Hatchery in Eagle, Idaho. Seven distinct broodstocks have been established by trapping outmigrating smolts, rearing a portion of the progeny of returning adults to adulthood, and by trapping residualized sockeye salmon within Redfish Lake. Although sockeye salmon have been cultured in Alaska for many years and guidelines for culturing them have become established (Mc Daniel et al. 1994), the limited numbers and status of the Snake River sockeye salmon make their success within the hatchery of utmost importance. A number of different culture strategies are being implemented at Eagle to try to improve sockeye salmon survival and spawning success. These strategies include modification of the standard brood diet to eliminate possible deficiencies, incubating eggs at different temperatures, and controlling mating crosses to expand the genetic base of the few remaining fish.

The objective of this study was to evaluate the effects of different culture techniques and diet modifications on the spawning success of Redfish Lake sockeye salmon. Evaluating these techniques may help fish culturists dealing with endangered salmonids to improve female quality and increase egg survival within the hatchery. 


\title{
METHODS
}

\author{
Fish Culture
}

Female performance and egg survival data was obtained from three distinct genetic groups of Redfish Lake sockeye salmon which spawned in the fall of 1994. Five hundred fortyeight fish were BY91 spawned from the four adults which returned to the lake. Another group consisted of fish captured as wild OM92. The third genetic group consisted of wild male OM91 and was used to fertilize the BY91 females.

Fish were raised on $13^{\circ} \mathrm{C}$ degassed well water from hatch (or capture) to adult. Densities were maintained at less than $16 \mathrm{~kg} / \mathrm{m}^{3}$ and feeding rates were equal (percent body weight/day) for all genetic types. All handling to monitor growth and/or move fish was similar for all groups of fish. Just prior to maturity, adults were transferred to $10^{\circ} \mathrm{C}$ chilled well water and remained at that temperature for up to two months before spawning.

Spawning matrices were established to increase the genetic diversity through non-sibling mating, or outcrossing, as much as possible. However, not enough OM91 males matured to fertilize all the BY91 females and some half-sibling matings occurred throughout the season. The resulting data allowed an investigation into the effects of half-sibling mating versus nonsibling mating on sockeye salmon egg survival.

\section{Spawning}

After sorting females for ripeness, individual males were anaesthetized in MS-222, swabbed with a solution of $100 \mathrm{ppm}$ Argentyne, and gametes stripped into 2-3 whirlpack bags labeled with the PIT tag number. Each time a male was used, sperm was examined under a microscope to check motility levels. Males with motilities under $70 \%$ were discarded.

Ripe females were euthanized and then air spawned (Erdahl 1993) to maintain body integrity for disease sampling. Eggs of individual females were weighed to the nearest gram and divided into four equal sub-lots. One-quart plastic bags were used for egg collection and division. Sperm from one male fertilized two of the sub-lots and the other two sub-lots were fertilized by a second male. An activator solution was added directly to the plastic bag to activate the sperm. After $3 \mathrm{~min}$, each sub-lot of eggs was rinsed in fresh water, placed into a one-quart upwelling incubator and water hardened in 100 ppm Argentyne for $\mathbf{3 0}$ min. During water hardening, each incubator was bar-code labeled with the PIT tag number, diet, and genetic type of both the male and the female along with the spawning date. After water hardening, one of the two sub-lots fertilized by a particular male was transferred to $5^{\circ} \mathrm{C}$ chilled well water for incubation, and the other sub-lot fertilized by the same male was incubated at $10^{\circ} \mathrm{C}$ chilled well water. The same process occurred for the other two sub-lots. This process allowed evaluation of the effect of two different incubation temperatures on egg survival.

Post-spawning information obtained from females included fecundity, weight, and egg size. Weight was extrapolated from fork length through a weight/length relationship developed from previous years' spawning and mortalities. Egg size was determined for each female during 
the first egg picking at eye-up as the number of eggs per gram (wet-weight). Fecundity was calculated by dividing the total weight of the four groups of eggs by egg size.

Initial fertilization was determined $48 \mathrm{~h}$ post-fertilization. If an individual sub-lot contained less than $1 \%$ viable eggs, the entire lot was removed from incubation. Physical counts were made on each remaining sub-lot at eye-up and swim-up to determine egg survival percentages.

\section{Diet Modifications}

Modifications were made to the standard $8 \mathrm{~mm}$ brood diet developed by Biodiet, Inc. For the "special" diet, $50 \%$ of the standard protein of fish meal was replaced with Antarctic krill to increase the carotenoid levels in and broaden the fatty acid profile of the diet. Also, the water at Eagle Fish Hatchery was determined to be deficient in selenium, an element found to increase female quality in salmonids. Thus, selenium was added as NaSe (@0.112 ppm Se) and Alltech yeast Se (@0.188). In addition to this, Vitamin E was increased to $30 \mathrm{lu} / \mathrm{kg}$ and Vitamin C was increased to $600 \mathrm{ppm}$ (added as C-polyphosphate [STAYCReg.Trad.]). There was no assessment made to determine caloric content of the diets. Approximately 6 months prior to spawning, $75 \%$ (6 tanks) of the BY91 fish were fed the special diet while $25 \%$ (2 tanks) received the standard brood diet. All of the OM92 fish and $66 \%$ of the OM91 fish received the special diet and the remainder received the standard diet. At maturity, female quality, diet, genetic type, and egg survival were monitored for each female by diet using its PIT tag number.

\section{Statistics}

Analysis of variance and Chi-square analysis were performed on the data using Systat (1994). For analysis of variance, the general linear models procedure was used to test for main effects and interactions. Pearson Chi-square was used to test for differences in the number matured by diet and initial fertilization by diet.

\section{RESULTS}

\section{Dies}

Nearly $84 \%$ of the BY91 broodstock matured during 1994. However, modifying the broodstock diet had no affect on the number of captive BY91 sockeye salmon which matured $(P=0.44)$ (Table 6). While initial fertilization was poor throughout the fall spawning season, the special broodstock diet did affect the percentage of females which had eggs that appeared to be fertilized after $48 \mathrm{~h}(P=0.02)$ (Table 7). Overall, nearly $50 \%$ of the eggs from females fed the special diet were initially fertilized versus $34 \%$ for the regular diet.

Evaluation of female performance and egg survival percentages was done only on females with viable eggs $48 \mathrm{~h}$ post-fertilization. Of the 234 females which matured during this 
spawning season, only $104(44 \%)$ produced viable eggs (Table 7 ). Six females were excluded from evaluation due to broken or mishandled incubators.

The special diet affected certain aspects of female performance. Female weight and egg size were significantly larger in those fish fed the special diet while fecundity and relative fecundity were not significantly different (Table 8).

Egg survival percentages were not affected by diet at either incubation temperature or when incubation temperatures were combined (Table 9).

\section{Iemperature}

Both eye-up and swim-up were significantly higher at $10^{\circ} \mathrm{C}$ incubation $(P<0.05)$ (Table 10) while the percent surviving from eye-up to swim-up was not significantly different between the two groups.

Table 6. The effect of diet on percent maturation of captive sockeye salmon broodstock.

\begin{tabular}{|c|c|c|c|c|}
\hline \multirow[t]{2}{*}{ Diet } & \multicolumn{3}{|c|}{ Number matured Number not matured Percent matured } & \multirow{2}{*}{$\begin{array}{l}P \\
0.44\end{array}$} \\
\hline & & & & \\
\hline Special & 404 & 72 & 85 & \\
\hline Regular & 144 & 31 & 82 & \\
\hline
\end{tabular}

Table 7. The effect of diet on initial fertilization ( $48 \mathrm{~h}$ ) of captive sockeye salmon broodstock.

\begin{tabular}{lccc}
\hline & \multicolumn{2}{c}{ nitial fertilization } & \\
\cline { 2 - 4 } Diet & Yes & & \\
& & & \\
Special & $79 / 158(50 \%)$ & $79 / 158(50 \%)$ & \\
Regular & $26 / 76(34 \%)$ & $50 / 76(66 \%)$ & \\
\hline
\end{tabular}

Table 8. The effect of diet on female performance of captively reared sockeye salmon (mean $\pm \mathrm{SE})$.

\begin{tabular}{lccccc}
\hline Diet & N & $\begin{array}{c}\text { Egg size } \\
(\text { eggs/g) }\end{array}$ & $\begin{array}{c}\text { Relative } \\
\text { fecundity }\end{array}$ & Fecundity & W e \\
Special & 73 & $7.84(0.11)$ & $1970154)$ & $874(23)$ & $2271(36)$ \\
Regular & 25 & $8.40(0.26)$ & $1954(103)$ & $928(45)$ & $2133178)$
\end{tabular}

\footnotetext{
'significant at 0.05 .

significant at 0.10 .
} 
Table 9. The effect of diet on egg survival percentages of captive Redfish Lake sockeye salmon at two incubation temperatures (mean $\pm \mathrm{SE}$ ).

\begin{tabular}{|c|c|c|c|c|}
\hline \multirow[b]{2}{*}{ Diet } & \multirow[b]{2}{*}{$\mathrm{N}$} & \multicolumn{3}{|c|}{ Incubation temperature $=\circ$} \\
\hline & & Eve-up & $\begin{array}{l}\text { Eye-up to } \\
\text { swim-up }\end{array}$ & S w i m-u \\
\hline \multirow[t]{2}{*}{ Regular } & $\begin{array}{l}73 \\
25\end{array}$ & $\begin{array}{l}50.1(3.8) \\
55.5(5.5)\end{array}$ & $\begin{array}{l}35.5(3.3) \\
38.2(4.8)\end{array}$ & $\begin{array}{l}64.2(2.9) \\
64.5(4.2)\end{array}$ \\
\hline & & \multicolumn{3}{|c|}{ Incubation temperature $=$} \\
\hline \multirow[t]{2}{*}{$\begin{array}{l}\text { Special } \\
\text { Regular }\end{array}$} & $\begin{array}{l}73 \\
25\end{array}$ & $\begin{array}{l}52.9(3.5) \\
57.6(5.9)\end{array}$ & $\begin{array}{l}38.1(3.4) \\
40.6(5.2)\end{array}$ & $\begin{array}{l}64.6(3.0) \\
66.8(4.1)\end{array}$ \\
\hline & & \multicolumn{3}{|c|}{ Incubation temoeratures combined } \\
\hline $\begin{array}{l}\text { Special } \\
\text { Regular }\end{array}$ & $\begin{array}{l}73 \\
25\end{array}$ & $\begin{array}{l}51.2(3.6) \\
56.5(5.4)\end{array}$ & $\begin{array}{l}36.7(3.2) \\
38.4(4.7)\end{array}$ & $\begin{array}{l}64.3(2.4) \\
65.1(3.7)\end{array}$ \\
\hline
\end{tabular}

Note: None of these groups are significantly different.

Table 10. Egg survival percentages of 98 captive sockeye salmon incubated at two temperatures (mean $\pm \mathrm{SE}$ ).

\begin{tabular}{llcr}
\hline & \multicolumn{3}{c}{ Eag survival percentages } \\
\cline { 2 - 4 } $\begin{array}{l}\text { Incubation } \\
\text { temperature }\end{array}$ & Fve-up & Swim-uo & $\begin{array}{c}\text { Eye-up to } \\
\text { swim-up }\end{array}$ \\
& $51.5(3.2)$ & $36.2(2.7)$ & $64.2(2.4)$ \\
$5^{\circ} \mathrm{C}$ & $54.1(3.0)$ & $38.8(2.9)$ & $65.2(2.5)$
\end{tabular}

"Significant at 0.05 .

\section{Ego Size}

To evaluate the effect of egg size on egg survival, egg size samples were grouped accordingly (Table 11). Egg size had a significant effect on swim-up and percent eye-up to swim-up at both incubation temperatures (Table 11). There was, however, no effect of egg size on eye-up $(P>0.25)$ at any temperature. The highest percent eye-up occurred with the largest egg size $(5.83 \mathrm{egg} / \mathrm{g})$ at $10^{\circ} \mathrm{C}$ incubation $(68.3 \%)$, while the lowest eye-up occurred with an egg size of $7.53 \mathrm{egg} / \mathrm{g}$ at $5^{\circ} \mathrm{C}$ incubation $(50.7 \%)$. The highest percent swim-up again occurred with the largest egg size at $10^{\circ} \mathrm{C}$ incubation, while the lowest was found with an egg size of $8.52 \mathrm{egg} / \mathrm{g}$ at $5^{\circ} \mathrm{C}$ incubation. Survival from eye-up to swim-up was highest with the largest egg size at $5^{\circ} \mathrm{C}$ incubation (82.0\%). The lowest survival was found at 8.52 eggs/g and $5^{\circ} \mathrm{C}$ incubation. With both incubation temperatures combined, the largest egg size resulted in the highest egg survival among all three categories. 
Table 11. The effect of egg size (number of eggs per gram) on egg survival percentages of Redfish Lake sockeye salmon at two incubation temperatures (mean $\pm S E$ ).

\begin{tabular}{|c|c|c|c|c|}
\hline \multirow[b]{2}{*}{ Ego size } & \multirow[b]{2}{*}{$\mathrm{N}$} & \multicolumn{3}{|c|}{ Incubation temperature $=5^{\circ}$} \\
\hline & & - & $\begin{array}{l}\text { Eye-up to } \\
\text { Swim-uo }\end{array}$ & Swim-ue ${ }^{b}$ \\
\hline $\begin{array}{l}5.83(0.11) \\
7.53(0.03) \\
8.52(0.06) \\
9.72(0.17)\end{array}$ & $\begin{array}{l}13 \\
45 \\
25 \\
15\end{array}$ & $\begin{array}{l}66.6(8.5) \\
50.7(4.9) \\
45.5(5.3) \\
52.0(8.9)\end{array}$ & $\begin{array}{l}52.2(9.3) \\
35.8(4.1) \\
28.4(4.1) \\
36.4(6.2)\end{array}$ & $\begin{array}{l}82.0(5.9) \\
62.1(3.8) \\
59.3(2.9) \\
64.2(7.3)\end{array}$ \\
\hline & & \multicolumn{3}{|c|}{ Incubation temperature $=$} \\
\hline $\begin{array}{l}5.83(0.11) \\
7.53(0.03) \\
8.52(0.06) \\
9.72(0.17)\end{array}$ & $\begin{array}{l}13 \\
45 \\
25 \\
15\end{array}$ & $\begin{array}{l}68.3(7.7) \\
52.8(4.5) \\
49.9(5.3) \\
52.9(8.5)\end{array}$ & $\begin{array}{l}59.0(8.4) \\
36.7(4.2) \\
34.1(5.3) \\
35.2(6.2)\end{array}$ & $\begin{array}{l}81.5(5.3) \\
63.1(4.1) \\
60.3(4.5) \\
65.7(4.4)\end{array}$ \\
\hline & & \multicolumn{3}{|c|}{ Incubation temperatures combined } \\
\hline $\begin{array}{l}5.83(0.11) \\
7.53(0.03) \\
8.52(0.06) \\
9.72(0.17)\end{array}$ & $\begin{array}{l}13 \\
45 \\
25 \\
15\end{array}$ & $\begin{array}{l}64.9(8.4) \\
51.7(4.6) \\
47.7(4.9) \\
52.5(8.6)\end{array}$ & $\begin{array}{l}55.7(8.7) \\
35.9(3.8) \\
31.2(4.4) \\
34.4(6.1)\end{array}$ & $\begin{array}{l}80.9(5.4) \\
63.4(2.9) \\
58.8(3.7) \\
62.9(5.0)\end{array}$ \\
\hline
\end{tabular}

"Significant at 0.10 .

Significant at $\mathbf{0 . 0 5}$.

\section{Genetic Cross}

The mating cross also affected egg survival percentages of captive sockeye salmon. Outcrossing increased eye-up, swim-up, and survival from eye-up to swim-up, although significant differences were observed only at $10^{\circ} \mathrm{C}$ incubation. Combining incubation temperatures revealed significant differences among eye-up percentages. Overall, the outmigrant $1992(\mathrm{~N}=3)$ females had the highest egg survival $(60.9 \%$ swim-up), while among the larger groups, outcrossed females incubated at $10^{\circ} \mathrm{C}$ had the highest egg survival $(45.5 \%$ swim-up). An investigation into possible differences in female quality among the groups uncovered no differences in egg size $(P=0.16)$, fecundity $(P=0.19)$, or weight $(P=0.33)($ Table 12).

For overall egg survival and female performance, see Table 13. 
Table 12. The effect of mating cross on egg survival percentages of captive Redfish Lake sockeye salmon at two incubation temperatures (mean $\pm \mathrm{SE}$ ).

\begin{tabular}{|c|c|c|c|c|}
\hline \multirow[b]{2}{*}{ Genetic tvoe } & \multirow[b]{2}{*}{ N } & \multicolumn{3}{|c|}{ Incubation temperature $=5^{\circ} \mathrm{C}$} \\
\hline & & Fve-uo & $\begin{array}{l}\text { Eye-up to } \\
\text { Swim-up }\end{array}$ & Swim-un ${ }^{b}$ \\
\hline \multirow[t]{2}{*}{$\begin{array}{l}\text { OM91 x BY91 } \\
\text { OM91 x OM92 } \\
\text { BY91 x BY91 }\end{array}$} & $\begin{array}{l}58 \\
03 \\
34\end{array}$ & $\begin{array}{l}53.8(4.2) \\
70.9(14.5) \\
46.2(5.1)\end{array}$ & $\begin{array}{l}38.3(3.6) \\
38.9(16.7) \\
32.5(4.2)\end{array}$ & $\begin{array}{l}64.3(2.8) \\
53.2(15.1) \\
65.1(4.7)\end{array}$ \\
\hline & & \multicolumn{3}{|c|}{ Incubation temperature $=0^{\circ}$} \\
\hline \multirow[t]{2}{*}{$\begin{array}{l}\text { OM91 x BY91 } \\
\text { OM91 x OM92 } \\
\text { BY91 x BY91 }\end{array}$} & $\begin{array}{l}58 \\
03 \\
34\end{array}$ & $\begin{array}{l}59.0(3.9) \\
72.7(11.4) \\
44.9(4.7)\end{array}$ & $\begin{array}{l}45.5(3.7) \\
60.9(18.7) \\
26.4(3.9)\end{array}$ & $\begin{array}{l}70.5(2.9) \\
80.2(11.5) \\
55.6(4.2)\end{array}$ \\
\hline & & \multicolumn{3}{|c|}{ Incubation temperatures combined } \\
\hline $\begin{array}{l}\text { OM91 x BY91 } \\
\text { OM91 x OM92 } \\
\text { BY91 x BY91 }\end{array}$ & $\begin{array}{l}58 \\
03 \\
34\end{array}$ & $\begin{array}{l}56.4(3.9) \\
72.0(11.4) \\
45.0(4.8)\end{array}$ & $\begin{array}{l}40.7(3.5) \\
49.6(17.7) \\
30.3(3.8)\end{array}$ & $\begin{array}{l}66.1(2.8) \\
65.7(13.3) \\
61.8(3.0)\end{array}$ \\
\hline
\end{tabular}

Significant at 0.05 .

Significance at 0.10 .

No difference in egg size, fecundity, or female weight between groups $(P=0.16,0.19,0.33)$.

Table 13. Egg survival and female performance for the 1994 fall spawning season.

\begin{tabular}{llllrrrrr}
\hline & \multicolumn{3}{c}{ Fve-uo } & Swim-uo & Swim & Fa g & \multicolumn{4}{c}{ Relative } \\
& & & & & & \\
& & & & & \\
Mean & $55.2 \%$ & $38.5 \%$ & $60.3 \%$ & 8.14 & 1,995 & 911 & 2,214 \\
Standard deviation & 18.0 & 15.0 & 20.0 & 0.80 & 235 & 95 & 121 \\
Minimum & 27.7 & 17.7 & 0.0 & 7.37 & 1,630 & 774 & 1,991 \\
Maximum & 78.0 & 69.2 & 79.5 & 10.57 & 2,480 & 1,135 & 2,427 \\
& & & & & & & \\
\hline
\end{tabular}

FACILITY MODIFICATIONS

\section{Water System Develooment}

Considerable modifications were made to the water supplies at Eagle Fish Hatchery to increase the volume from wells 1 and 2 and to provide an intertie between these wells and the hatchery building. Construction was done by IDFG personnel and Trammels, Inc. of Boise, Idaho without loss to fish being raised on station. Most modifications were made during the period of May to December 1994. 
The following modifications were made as a sequence:

1. A degasser was installed for B raceway tanks. This allowed the B section to be used for broodstock rearing during the construction phase.

2. Raceways $C$ and $D$ were prepared for tanks by removing the center wall, installing a center drain channel in each, and installing valves at the head end.

3. A temporary water supply line was placed in A and B sections during construction on the permanent water line.

4. A permanent degassing tower was installed near well 2 with associated plumbing and supply lines from both wells.

5. Submersible $50 \mathrm{HP}$ pumps were placed into both wells 1 and 2 and tied into the degasser. This allows the artesian supply to be used without the pumps operating.

6. A backup generator and associated controls were placed near well 2 .

7. Alarms for water flow were placed into B section and lines were run for C and D sections.

8. A $4 \mathrm{~m}$ head control tower was installed at the terminal end of the supply line for the raceways. This will increase the pressure and supply volume of water from the degassing tower.

9. Water supplies were tied in between the line for A, B, C, and D sections (east section) and the supply for the hatchery building. A filling tower was placed at the terminal end of this intertie line to provide fish hauling trucks with a mix of water temperatures.

10. A water chiller (and associated plumbing) was placed adjacent to the hatchery building to supply the hatchery building and adjacent area with cold water for adults holding prior to spawning. Several alarms were installed in these lines for water flow and level.

11. The main line had to be replaced at the head end of the east sections.

Generally, all the above construction was conducted without placing the fish in the A and $B$ sections at jeopardy. Water flows were not interrupted for more than one hour and oxygen was available during those periods.

\section{Rearina Capacity Increases at Eagle Fish Hatchery}

A quonset-style cover was installed over $C$ and $D$ sections. This was erected by the NMFS Engineering crew from Pasco, Washington with help from the Eagle Fish Hatchery crew. Poultry weave was installed to exclude avian predators.

Tanks were purchased for $C$ and $D$ sections from Aquafarms - Feversham, Ontario, Canada. The principle of having moveable tanks with interchangeable parts and plumbing has 
been valuable in this program to date, allowing tanks to be moved to several locations depending on the inventory of the several genetic types of fish being reared.

A total of 1,100 individual, sub-family incubators were fabricated prior to the spawning season. Plumbing for incubation inside $1 \mathrm{~m}$ tanks was designed to be removable. Most of the incubators were used during 1994.

\section{Additional Capital Purchases}

A hauling tank with an operating capacity of 1,150 liters was purchased for the hatchery truck. This has been outfitted with an oxygen supply line and water agitators and is ready for the releases of 1995 .

A YSI (Yellow Springs Instrument Co.) dissolved oxygen/water temperature meter with a probe depth of $16 \mathrm{~m}$ was purchased for net pen monitoring.

\section{Major Maintenance Projects}

The interior of Residence 1 at Eagle Fish Hatchery was remodeled after having been used as office space for the IDFG Fisheries Research group. This has now become the residence for the Assistant Fish Hatchery Manager.

Siding for Residence 2 was purchased and is ready for installation. 


\section{ACKNOWLEDGMENTS}

Funding for the captive broodstock program has come from the Bonneville Power Administration. The efforts of our contract officer, Dr. Jeffrey Gislason, in solving budget issues in a timely manner have always been appreciated.

The professionalism of the members of the Stanley Basin Sockeye Technical Oversight Committee has contributed in a great measure to the progress in this program. We routinely receive constructive debate and resolve contentious problems. The relationships between agencies have been very positive as the result of the process. Research on the genetics of sockeye salmon and kokanee of Redfish Lake has been particularly useful to our program at spawning time since it allowed for matings to be made without concern for having kokanee genetics issues to deal with.

The staff of Sawtooth Fish Hatchery played an important role in trapping and holding of the single anadromous adult of 1994. Their help has made this work consistently enjoyable and efficient. Their help has again been appreciated.

We would like to thank those whose responsibilities include the daily culture of the broodstock and production sockeye salmon. The responsibilities can become overwhelming, but we appreciate the cheerfulness of our staff. Each group of presmolts that we put into Redfish Lake lessens the anxiety level of all of us in the program and we want to commend the fish culturists for their quality work on recovery of this stock.

Special thanks to Paul Kline for his never-ending help during spawning and other important fish-related projects. We would also like to thank him for his critical review of this manuscript.

At the end of the reporting period, the staff at Eagle Fish Hatchery consisted of Keith Johnson, Project Leader; Steve Wingert, Assistant Fish Hatchery Manager; Jay Pravecek, Fish Culturist; and two part-time temporary technicians - Bryan Profit and Megan Heinrich. Ryan Johnson, former fish culturist for the project, accepted a position in fish culture in Alaska and left in December. His efforts and dedication were responsible for much of the progress for the last three years, and we wish him the best in his future career. 


\section{LITERATURE CITED}

Bjornn, T.C., D.R. Craddock, and D.R. Corley. 1968. Migration and survival of Redfish Lake, Idaho sockeye salmon Oncorhynchus nerka. Transactions of the American Fisheries Society, 97(4):360-373.

Brannon, E., A. Setter, T. Welsh, R. Danner, K. Collins, M. Casten, G. Thorgaard, K. Adams, and S. Cumings. 1994. Genetic analysis of Oncorhynchus nerka: life history and genetic analysis of Redfish Lake Oncorhynchus nerka. Completion report to U.S. DOE, Bonneville Power Administration, Environment, Fish and Wildlife. Contract No. DE-BI7990BP12885. Portland, Oregon. $48 \mathrm{pp}$.

Erdahl, D. 1993. Inland Salmonid Broodstock Management Handbook. US. DOI, Fish and Wildlife Service. Bozeman, Montana. $137 \mathrm{pp}$.

Johnson, K. 1993. Research and Recovery of Snake River Sockeye Salmon. Idaho Department of Fish and Game Annual Report, 1992 to U.S. DOE, Bonneville Power Administration, Division of Wildlife. Contract No. DE-BI79-91 BP21 065. Portland, Oregon. 38 pp.

Johnson, K.A. and J.J. Pravecek. 1996. Research and Recovery of Snake River Sockeye SaImon. Idaho Department of Fish and Game Annual Report, 1993 to U.S. DOE, Bonneville Power Administration, Division of Wildlife. Contract No. DE-BI7991BP21065. Portland, Oregon. 42 pp.

Kline, P. 1994. Research and Recovery of Snake River Sockeye Salmon. Idaho Department of Fish and Game Annual Report, 1993 to U.S. DOE, Bonneville Power Administration, Division of Wildlife. Contract No. DE-B179-91BP21065. Portland, Oregon. 52 pp.

Kline, P. 1995. Research and Recovery of Snake River Sockeye Salmon. Idaho Department of Fish and Game Annual Report, 1994 to U.S. DOE, Bonneville Power Administration, Division of Wildlife. Contract No. DE-BI79-91BP2065. Portland, Oregon. 47 pp.

Lane, M. Personal Communication. February 1994.

McDaniel, T.R., K.M. Pratt, T.R. Meyers, T.D. Ellison, J.E. Follett, and J.A. Burke. 1994. Alaska Sockeye Salmon Culture Manual. Special fisheries report number 6. Alaska Department of Fish and Game, Juneau.

McNeil, W.J. and J.E. Bailey. 1975. Salmon Rancher's Manual. Northwest Fisheries Center Processed Report. National Marine Fisheries Service. Auke Bay, Alaska.

Smith, C.E. 1971. An undifferentiated hematopoietic neoplasm with histologic manifestations of leukemia in a cutthroat trout (Salmo clarki). Journal of the Fisheries Research Board of Canada 28:112-113.

Smith, C. E. 1993. Neoplasia in salmonids. In: Fish Medicine, 1st Edn (ed. by M.K. Stoskopf), pp. 428-431. W. B. Saunders. Philadelphia, Pennsylvania. 
APPENDICES 


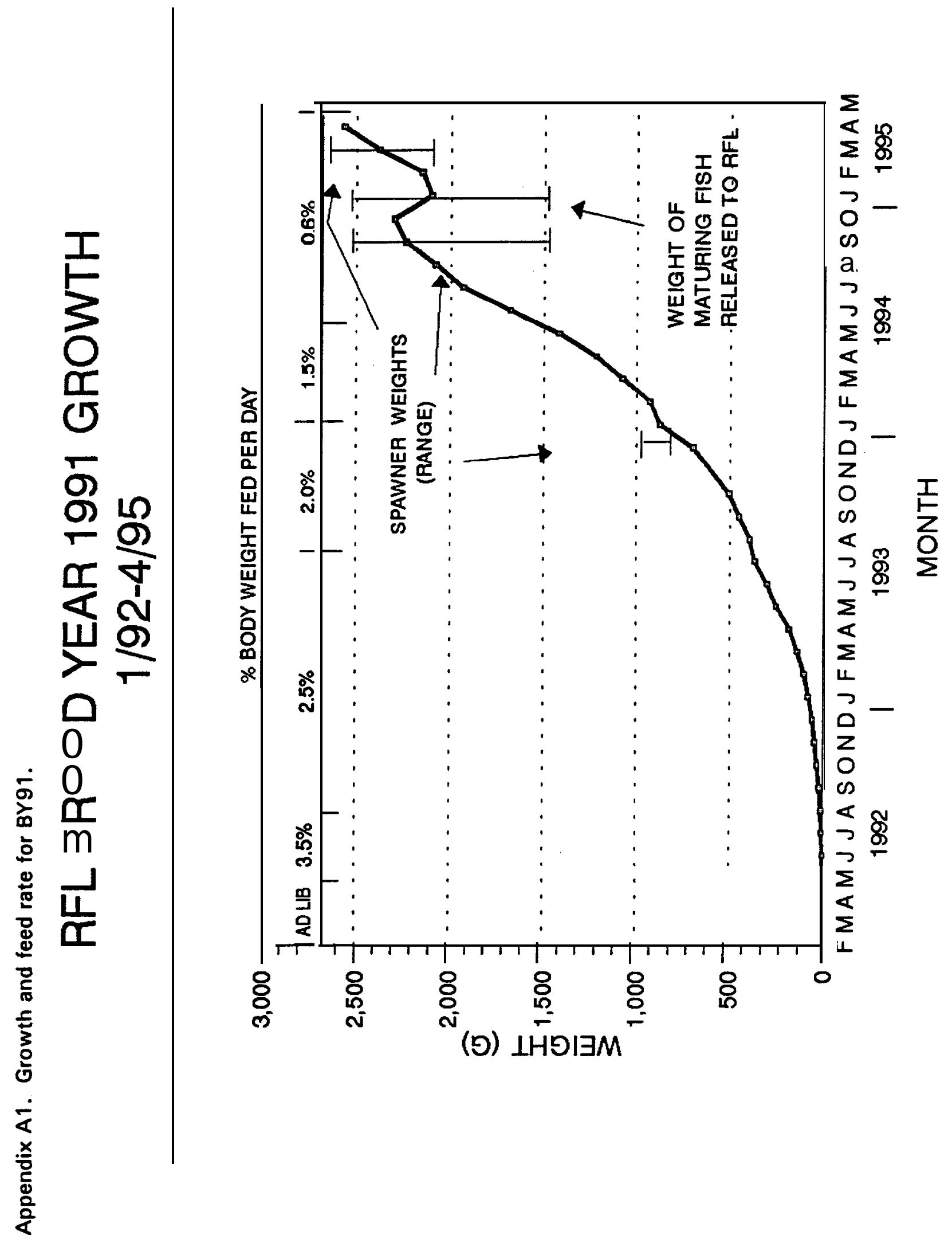




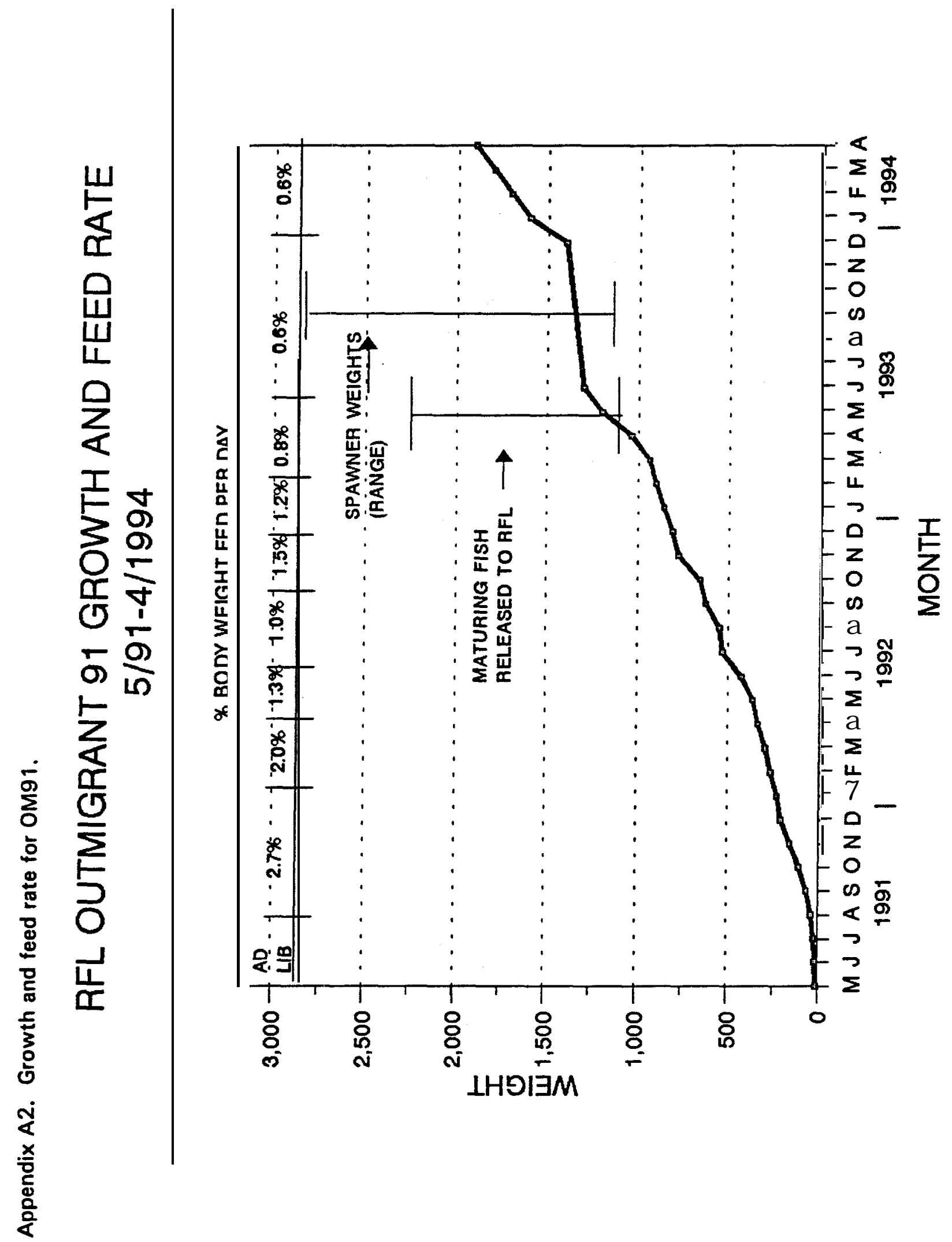



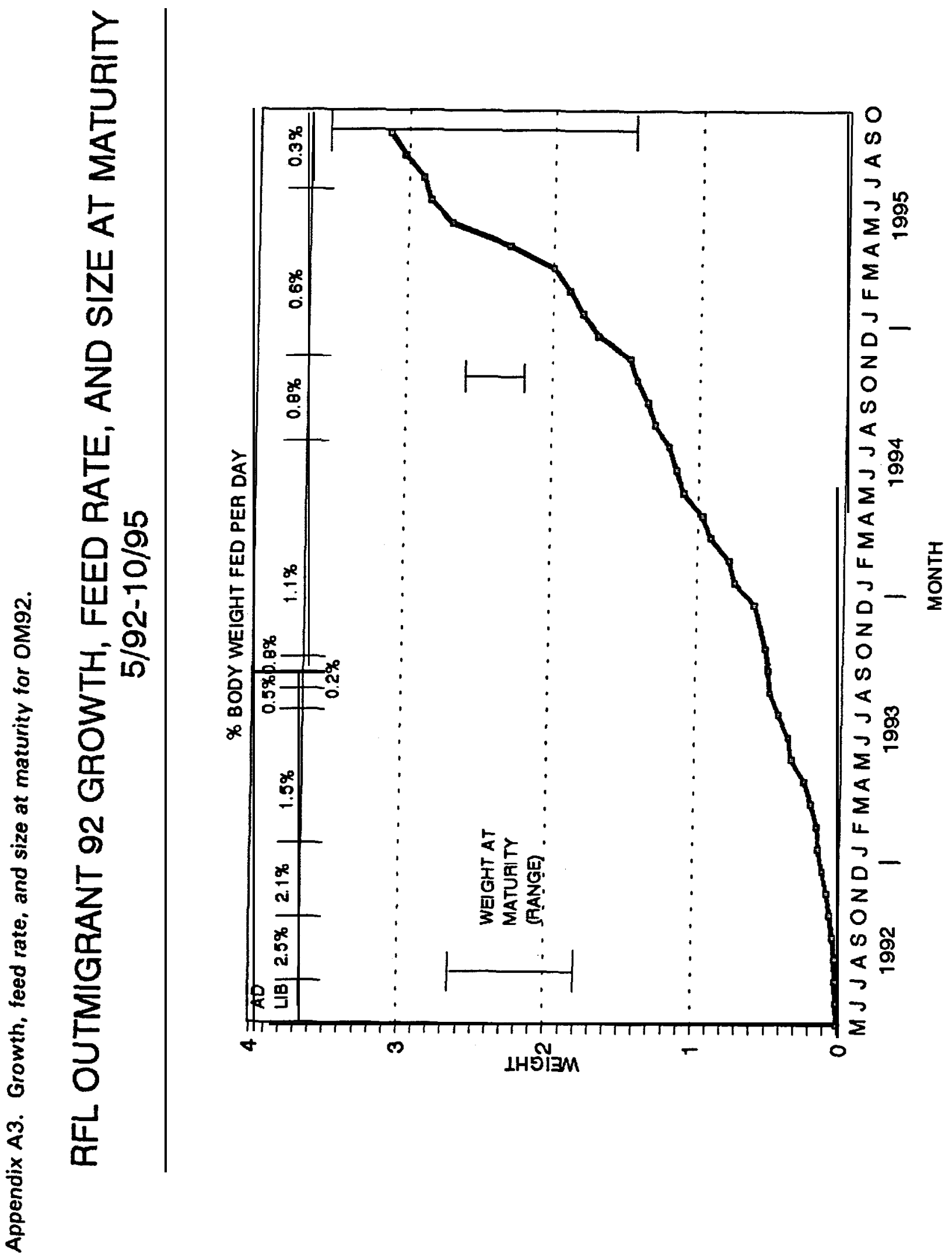


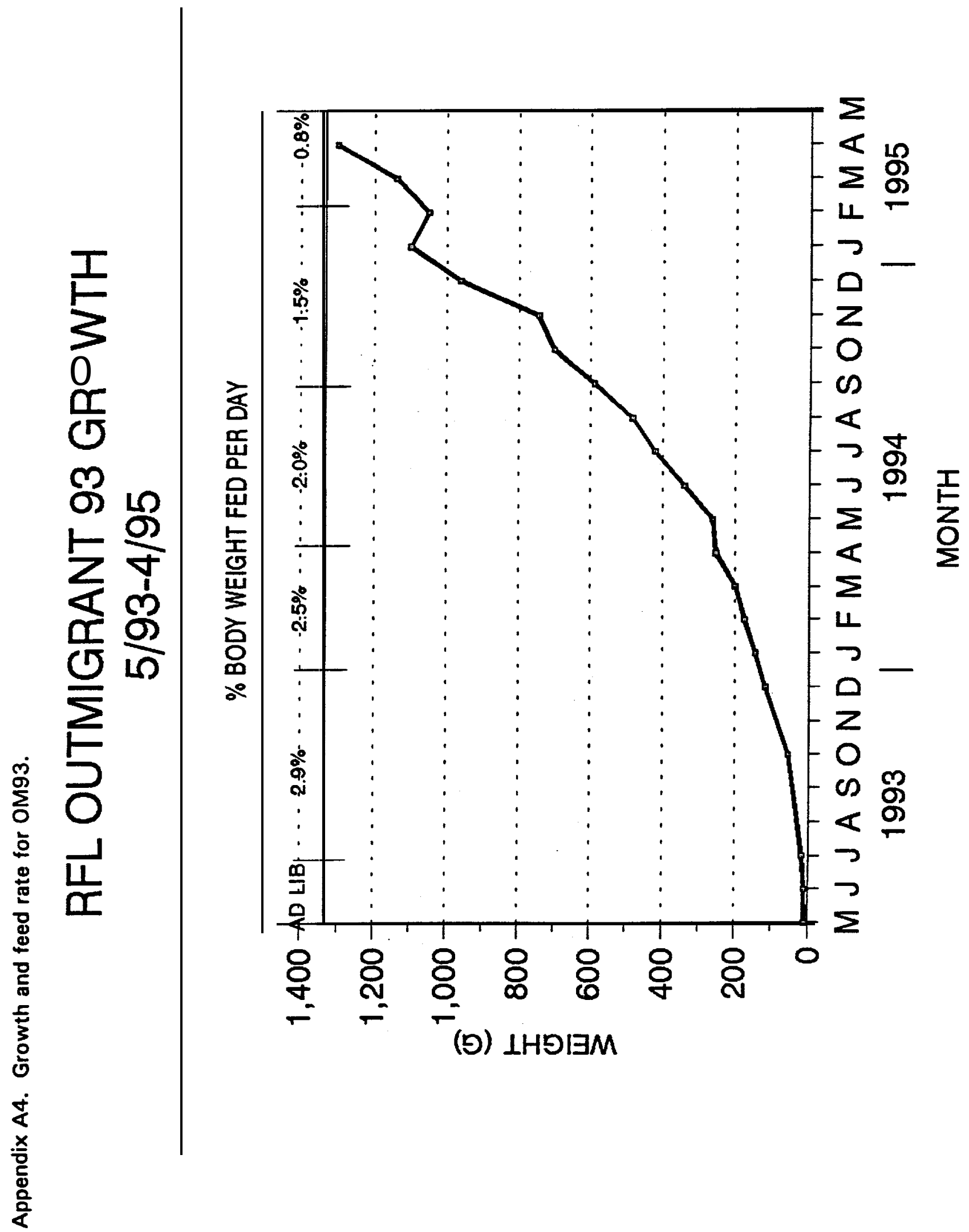




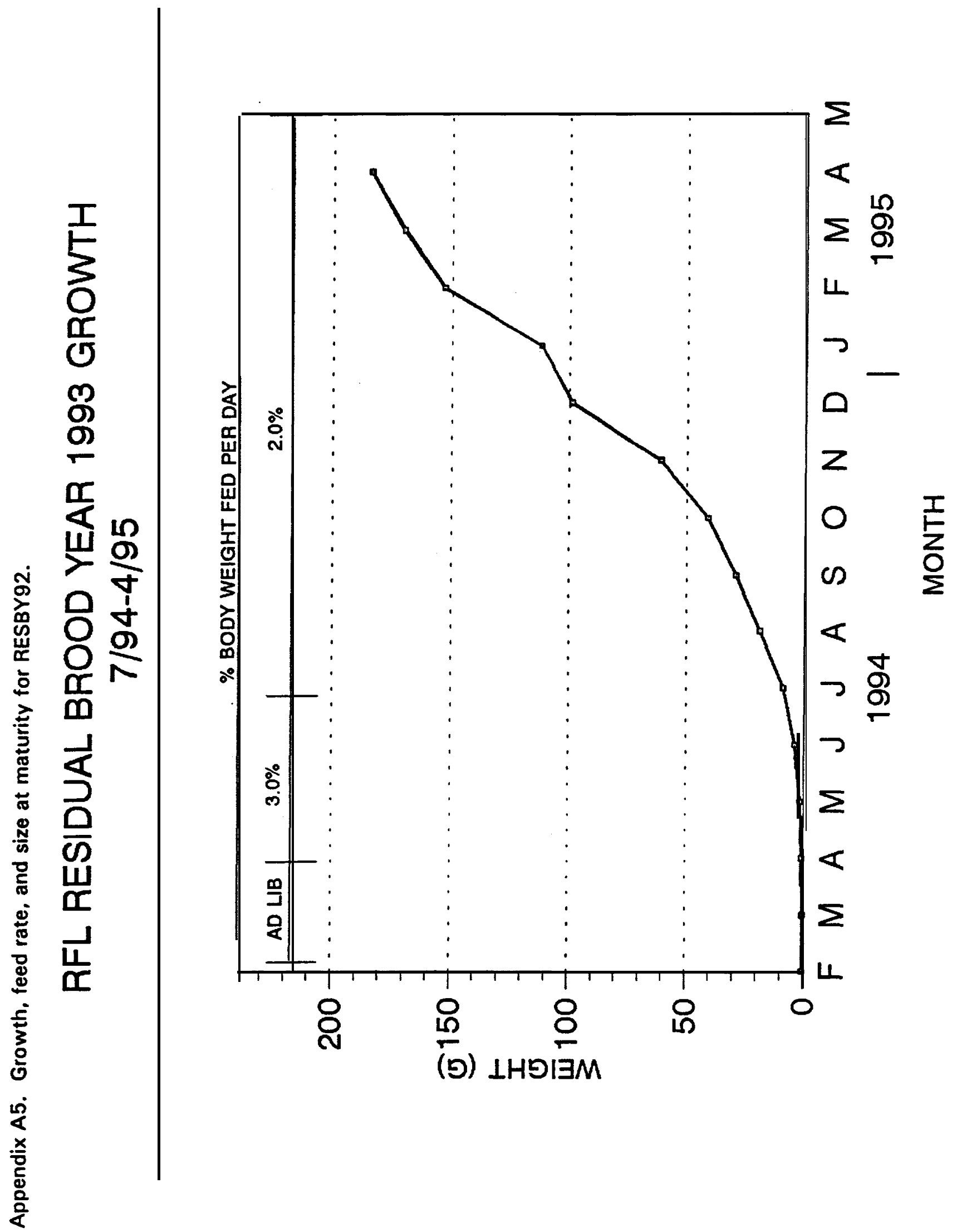




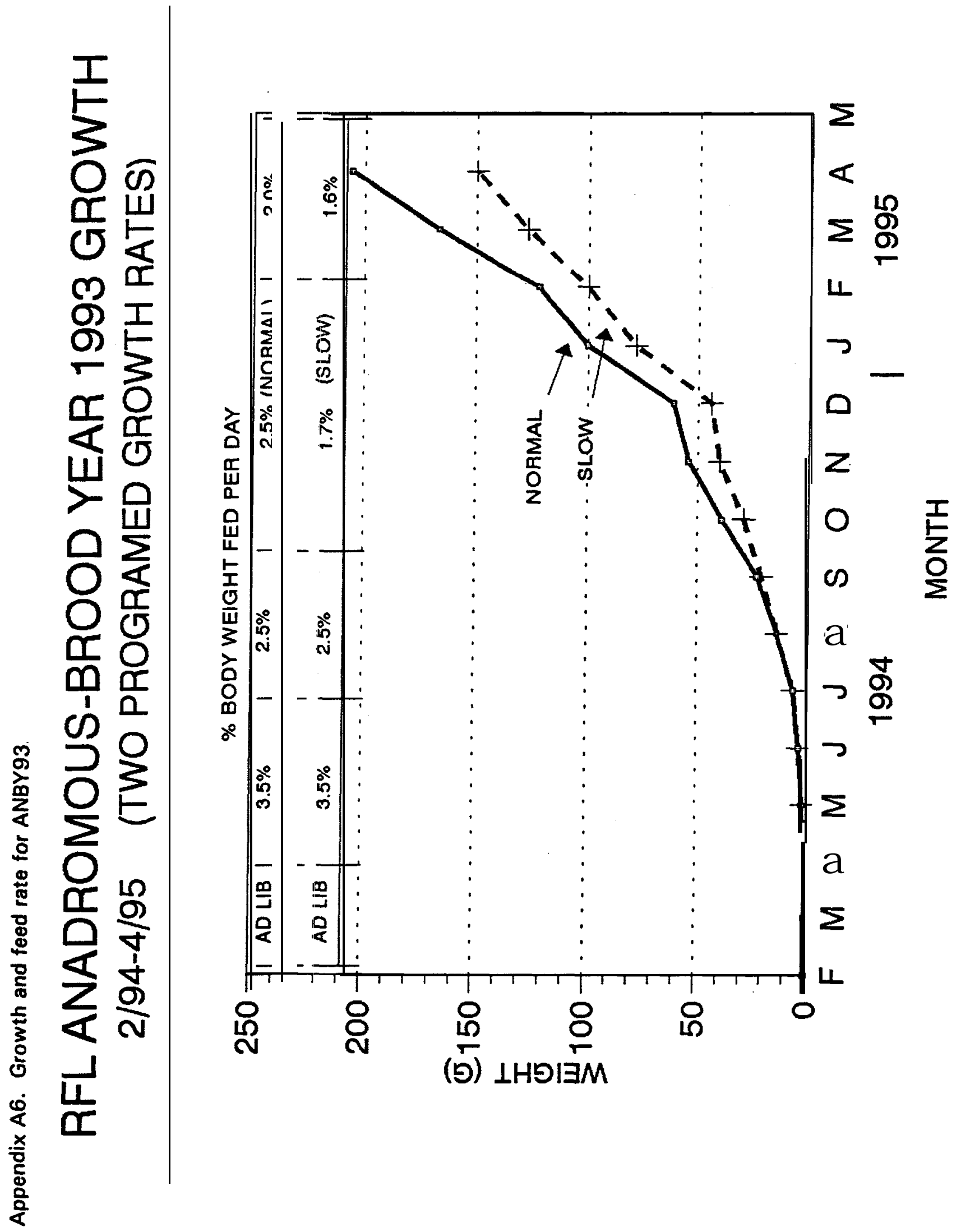




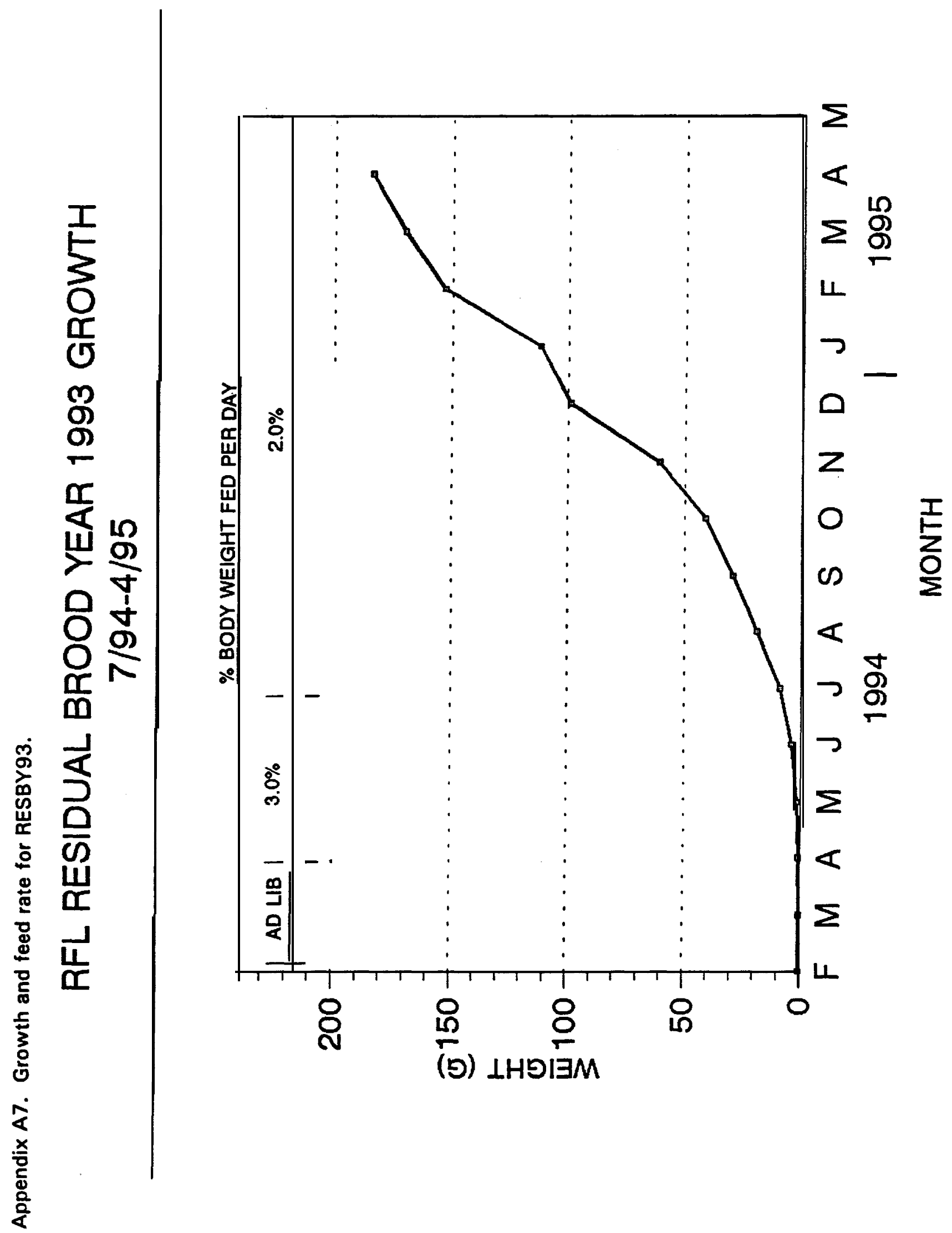




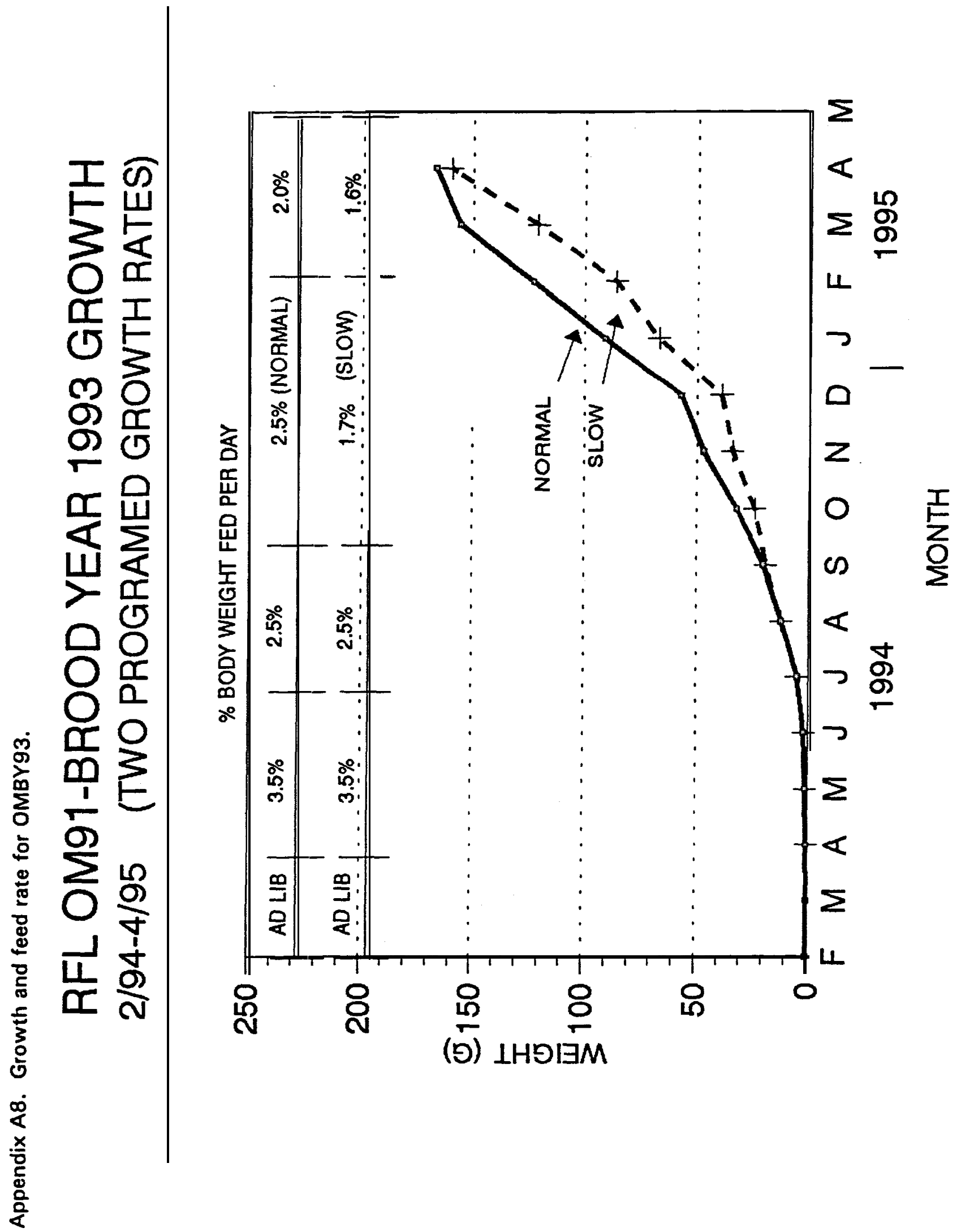


Appendix B. Mating crosses made with anadromous, captive broodstock, and residual adults of Redfish Lake stock during the period of April 1994 through November 1994. Number of females listed first followed by the number of males used by genetic origin.

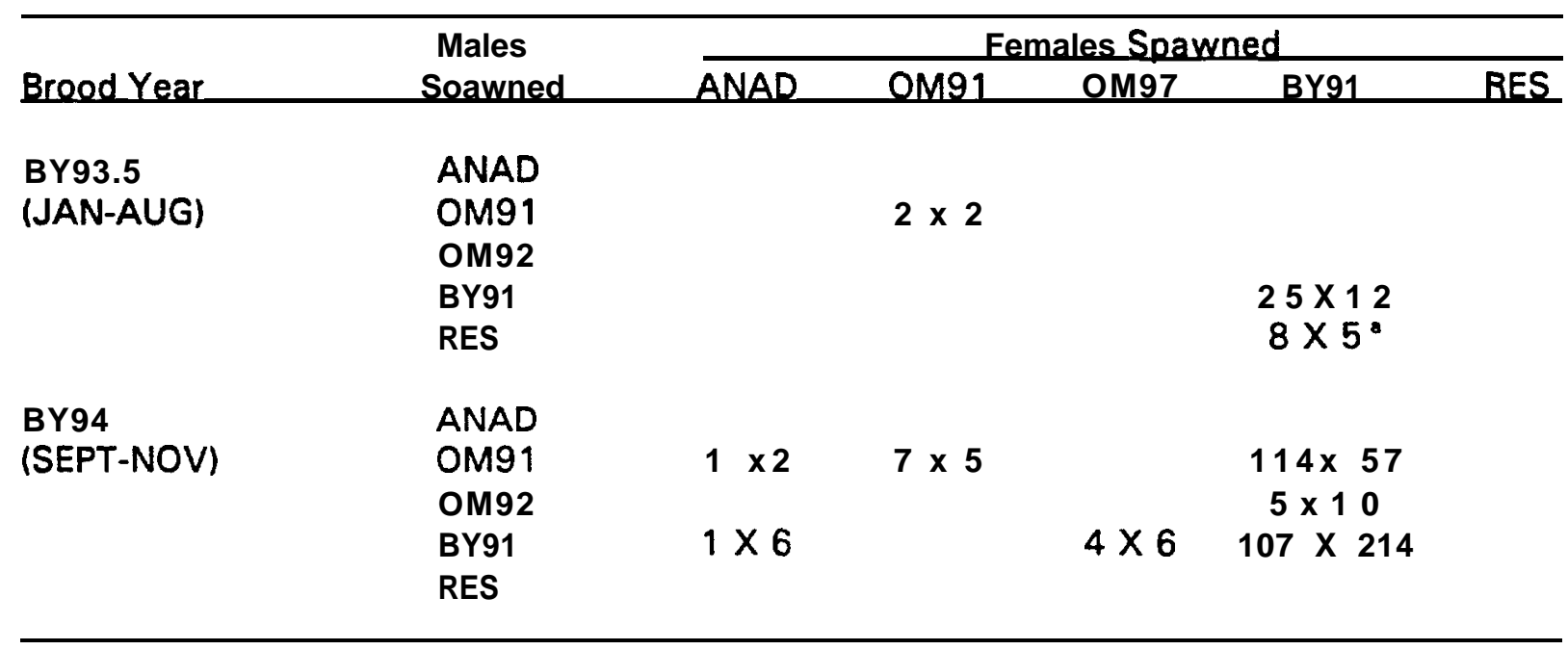

"Cryopreserved sperm used since no fresh sperm was available.

Appendix C. Adult releases to Redfish Lake for 1994.

\begin{tabular}{|c|c|c|c|c|}
\hline Date & Broodsteck & Number & Sex & Weight(g) \\
\hline $8 / 9 / 94$ & $\begin{array}{l}\text { BY91 } \\
\text { BY91 }\end{array}$ & $\begin{array}{r}10 \\
1\end{array}$ & $\begin{array}{l}\text { FM } \\
\text { M }\end{array}$ & $\begin{array}{l}2,070 \\
2,070\end{array}$ \\
\hline $8 / 11 / 94$ & $\begin{array}{l}\text { OM91 } \\
\text { OM91 }\end{array}$ & $\begin{array}{r}4 \\
11\end{array}$ & $\begin{array}{l}\text { FM } \\
\text { M }\end{array}$ & $\begin{array}{l}2,420 \\
2,420\end{array}$ \\
\hline & OM92 & 2 & $\mathbf{F M}$ & 1,820 \\
\hline $9 / 10 / 94$ & $\begin{array}{l}\text { BY91 } \\
\text { BY91 }\end{array}$ & $\begin{array}{l}4 \\
5\end{array}$ & $\begin{array}{l}\text { FM } \\
\text { FM }\end{array}$ & $\begin{array}{l}2,560 \\
2,560\end{array}$ \\
\hline & $\begin{array}{l}\text { OM91 } \\
\text { OM91 }\end{array}$ & $\begin{array}{l}3 \\
4\end{array}$ & $\begin{array}{l}\text { FM } \\
\text { M }\end{array}$ & $\begin{array}{l}3,042 \\
3,042\end{array}$ \\
\hline $10 / 5 / 94$ & REBY92 & 19 & $\mathbf{M}$ & 500 \\
\hline
\end{tabular}


Prepared by:

Keith A. Johnson

Principal Fishery Research Biologist

Jay J. Pravecek

Fish Culturist
Approved by:

IDAHO DEPARTMENT OF FISH AND GAME

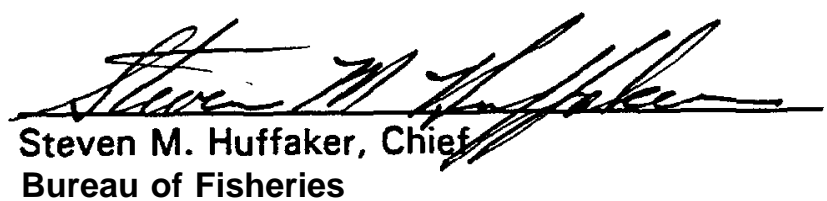

Bureau of Fisheries

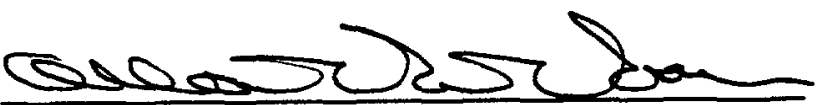

Allan R. Van Vooren

Fisheries Research Manager 